\title{
Rapid plant rehydration initiates permanent and adverse changes in the photosynthetic apparatus of triticale
}

\author{
Tomasz Hura • Katarzyna Hura • Agnieszka Ostrowska • \\ Kinga Dziurka
}

Received: 29 May 2015 / Accepted: 13 July 2015 / Published online: 26 July 2015

(C) The Author(s) 2015. This article is published with open access at Springerlink.com

\begin{abstract}
Background and aims The reasons for partial recovery after a soil drought are not fully understood and have not been studied so far. This study investigated the physiological and biochemical responses of triticale cultivars with differential recovery ability after soil water deficit. Methods Activity of the photosynthetic apparatus under soil drought followed by rehydration was estimated. Plant antioxidant potential was determined based on the measurement of catalase and peroxidase activity. The levels of hydrogen peroxide and superoxide radical were assessed.

Results Under rehydration, the not fully-recovered cultivar experienced further significant increase in the content of $\mathrm{H}_{2} \mathrm{O}_{2}$ and inhibited activity of the photosynthetic apparatus, as compared to the drought period. On $42^{\text {nd }}$ day of the rehydration, the not fully-recovered cultivar showed also a reduced photosynthetic activity in the flag leaves, which resulted in a significant decrease in its
\end{abstract}

Responsible Editor: Rafael S. Oliveira,.

Electronic supplementary material The online version of this article (doi:10.1007/s11104-015-2607-1) contains supplementary material, which is available to authorized users.

T. Hura $(\bowtie) \cdot$ A. Ostrowska $\cdot$ K. Dziurka

The Franciszek Górski Institute of Plant Physiology, Polish Academy of Sciences, Niezapominajek 21, 30-239 Kraków, Poland

e-mail: t.hura@ifr-pan.edu.pl

K. Hura

Department of Plant Physiology, Faculty of Agriculture and Economics, Agricultural University, Podłużna 3,

30-239 Kraków, Poland grain yield. The first week of a rapid rehydration involved a decrease in total peroxidase and catalase activities. The increased content of $\mathrm{H}_{2} \mathrm{O}_{2}$ was compensated only when leaf water content was gradually restored in the first week of the rehydration and no further decrease in the activity of the photosynthetic apparatus was noticed.

Conclusions A destructive effect of the rapid rehydration was manifested in an intensification of the physiological processes associated with reactive oxygen species (ROS) overproduction. An important cause of hydrogen peroxide overproduction seems to be the electron leakage due to overloading of the electron transport chain (ETC) in the PSI and PSII.

Keywords Rapid rehydration · Triticale · Hydrogen peroxide $\cdot$ Photosynthetic apparatus $\cdot$ Red and far-red fluorescence Blue fluorescence

\section{Introduction}

Soil drought is one of disadvantageous environmental factors significantly affecting the productivity of cereal crops (Cannell et al. 1984; Shah and Paulsen 2003; Hura et al. 2007a). The extent of grain yield loss depends on the intensity of the soil drought, i.e., whether the drought is mild or acute, its duration, frequency, plant growth stage during which adverse soil moisture conditions occur, and the efficiency of plant rehydration after the soil drought ceases (Souza et al. 2004; Barnabás et al. 2008). 
Rehydration, i.e., favorable soil moisture conditions following a drought (Beckett et al. 2012), is a period when plant physiological activity can return to the optimum, or even rise above the normal level, as in the case of the photosynthetic apparatus (Hura et al. 2009a, b, c). However, rapid plant rehydration may also cause adverse effects, such as an oxidative burst of hydrogen peroxide. This is often observed in mosses and lichens following a desiccation period, and the main reasons for reactive oxygen species generation seem to be extracellular and intracellular peroxidases, high light intensity or specifically localized the plasma membrane NADPH and NADH (Minibayeva and Beckett 2001; Mayaba et al. 2002; Weissman et al. 2005). Other studies showed that full recovery of plants when restoring favorable soil moisture conditions also depended on the mechanisms related to hydraulic failure and carbon starvation (McDowell et al. 2008; Sala et al. 2010; O'Grady et al. 2013; Sevanto et al. 2014).

Full recovery of crops after a drought means restoring normal cellular metabolism, manifested by the yield corresponding to optimal conditions of plant growth. In the case of winter triticale, soil drought at the heading or anthesis stage causes the greatest yield loss (Saini and Westgate 2000; Yang and Zhang 2006). Restoring favorable soil moisture conditions does not result in full recovery of the crops, as the plants are at the final growth stages. Contrary to that, full recovery of winter triticale is very often observed following the soil drought occurring at the tillering stage (Hura et al. 2006; 2009a, b, c). However, for some cultivars, even a long rehydration period after a drought experienced at the tillering stage is still insufficient and is manifested by unexpectedly large grain yield reduction.

The reasons for partial recovery after a soil drought are not fully understood and have not been studied so far. Majority of papers on rehydration emphasize its 'beneficial' effects on plant growth following a drought cessation (Srivalli et al. 2003; Hura et al. 2006, 2009a; Lovisolo et al. 2008; Beckett et al. 2012; Furlan et al. 2014). There are few publications addressing the adverse effects of the rehydration period on plant regeneration following the soil drought. Therefore, the aim of the experiment presented in this paper was to determine the physiological and biochemical responses of triticale cultivars with differential recovery ability after soil water deficit experienced at the tillering stage. To evaluate whether rapid rehydration causing intensification of metabolic processes could be the only source of hydrogen peroxide burst, we hypothesized that permanent and adverse changes in the activity of the photosynthetic apparatus are initiated by rapid rehydration following the drought, regardless light availability. This research hypothesis was verified in experimental conditions allowing for assessing the effects of light and different rehydration rates at which optimum soil water content was restored. Our study focused on the level of hydrogen peroxide, which on the one hand is considered to be a biological indicator of stress intensity (Bartosz 1997; Blokhina et al. 2002; Hura et al. 2014), and on the other hand is a secondary messenger in the signal transduction pathways leading to gene expression in response to adverse environmental factors (OrozcoCárdenas et al. 2001; Maksymiec 2007).

\section{Materials and methods}

\section{Plant material}

As presented in Table 1S, the experiment included one not fully-recovered cultivar 'Kazo' and one fully-recovered cultivar 'Hortenso' of winter triticale (x Triticosecale Wittmack). These cultivars are not significantly different in terms of physiological and biochemical responses to drought stress. The data presented in the table are the results of pot experiments conducted under controlled greenhouse conditions in the years 2008-2010. The seeds were obtained from 'DANKO' Plant Breeders Ltd., Choryń, Poland. The part of the experiment concerning plant growth was carried out in air-conditioned chambers and greenhouses of the Department of Plant Physiology, Faculty of Agriculture and Economics at the University of Agriculture in Kraków, Poland.

Plant growth conditions

The seeds of 'Kazo' and 'Hortenso' cultivars were sown into plastic pots $3.7 \mathrm{~L}$ in volume. Before sowing, the pots were tared to equal weight and filled with a homogeneous mixture of soil and sand $(1: 3 ; v / v)$. The seeds were sown with a surplus, i.e., 9 seeds per pot, and after the emergence, the number of plants per pot was limited to 7 .

The experiment covered an entire growth cycle of winter triticale from germination to ripening. Therefore, the seedlings at the stage of 2 leaves were subjected to vernalization in cold chambers, lasting for 7 weeks at + $3{ }^{\circ} \mathrm{C}\left( \pm 1{ }^{\circ} \mathrm{C}\right.$ ), and PPFD (photosynthetic photon flux 
density) of $150 \mu \mathrm{mol} \mathrm{m} \mathrm{m}^{-2}$, photoperiod $10 \mathrm{~h}$. After the vernalization, the plants at the 4-leaf stage were transferred into air-conditioned greenhouse chambers. Air temperature in the greenhouse was $28 / 18^{\circ} \mathrm{C}\left( \pm 2{ }^{\circ} \mathrm{C}\right)$ day/night, and relative air humidity was about $40 \%$. The plants were additionally illuminated to ensure that the PPFD was about $250 \mu \mathrm{mol} \mathrm{m} \mathrm{m}^{-2} \mathrm{~s}^{-1}$ (provided by high pressure sodium lamps, $400 \mathrm{~W}$; Philips SON-T AGRO, Brussels, Belgium), at the level of the top leaf. Light intensity at the leaf level was measured with a QSPAR Quantum Sensor (Hansatech Instruments LTD, Kings Lynn, England). The plants were irrigated once a week with full-strength Hoagland's nutrient solution (Hoagland 1948).

\section{Drought conditions}

The treatment of low water availability was initiated when the plants of both cultivars developed three leaves on the main shoot and two lateral shoots with 3 and 2 leaves ( 8 leaves in total). Water content in the pots was gradually lowered to $30 \%$ (about $-5.46 \mathrm{MPa}$ ) by not watering the plants for 7 days, and these conditions were maintained for the next 2 weeks. Water content in the control pots was maintained at $75 \%$ (about $-0.31 \mathrm{MPa}$ ). Water content in the pots for each treatment was set based on the maximum water holding capacity of soil and sand mixture. Soil moisture level in the pots was monitored daily between 8 and 10 a.m., using the gravimetric method and taking into account the weight of the plants. An increase in the fresh weight of the plants was determined at the harvest to adjust the correct level of soil moisture.

\section{Rehydration}

By the end of the soil drought period both cultivars developed a 5-leaf main shoot and one 3-leaf lateral shoot ( 8 leaves in total). Control plants of both cultivars developed a 5-leaf main shoot and two lateral shoots with 4 and 3 leaves (12 leaves in total).

The soil drought at the tillering stage was followed by three different schemes of rehydration:

Rehydration 1 (R1). Immediate restoration of soil water content up to $75 \%$ for PPFD of $250 \mu \mathrm{mol} \mathrm{m}{ }^{-2} \mathrm{~s}^{-1}$.

Rehydration 2 (R2). Gradual restoration of soil water content up to $75 \%$ for PPFD of
$250 \mu \mathrm{mol} \mathrm{m} \mathrm{m}^{-2} \mathrm{~s}^{-1}$. The soil water content was maintained at $40 \%$ for the first 2 days, then at $50 \%$ for the next 2 days, at $60 \%$ for 1 day and at $75 \%$ for the last 2 days.

Rehydration 3 (R3). Immediate restoration of soil water content up to $75 \%$ for PPFD of $25 \mu \mathrm{mol} \mathrm{m}{ }^{-2} \mathrm{~s}^{-1}$.

R2 and R3 treatments were applied only in the case of not fully-recovered 'Kazo' cultivar.

\section{Measurements}

The analyses were performed 14 days after the pot soil water content reached $30 \%$. Additionally, 1, 3 and 7 days after the rehydration, the activity of peroxidase and catalase was evaluated, and hydrogen peroxide and water content in the leaves were assessed. Chlorophyll fluorescence, gas exchange and emission intensity of blue and red fluorescence were measured 7 days after the rehydration. The analyses involved the second (from the top) fully developed leaf. Furthermore, on $42^{\text {nd }}$ day of the rehydration, the measurements were repeated for the flag leaves at the anthesis stage in both cultivars. Total catalase and peroxidase activity was recalculated for protein content according to Bradford (1976).

\section{Soil water content (SWC)}

The soil water content was estimated by measuring the fresh weight of the soil without plant residues and then the dry weight after $24 \mathrm{~h}$ of drying in an oven at $90{ }^{\circ} \mathrm{C}$. Soil samples $(100 \mathrm{~g})$ were taken from three pots within treatments, every other day for 2 weeks in the drought variant and every day for 7 days since the end of the drought period in the rehydration variant. SWC analysis in the control samples was run in parallel for the last 7 days of the drought period and 7 days of the rehydration every other day. When the plants were in the generative phase, SWC was analyzed on $36^{\text {th }}, 38^{\text {th }}, 40^{\text {th }}$ and $42^{\text {nd }}$ day of the rehydration (data not shown).

Midday relative water content (RWC) and predawn leaf water potential $\left(\Psi_{\mathrm{w}}\right)$

Relative water content (RWC) of the leaves was calculated as per the following equation: $\mathrm{RWC}(\%)=(\mathrm{fw}-\mathrm{dw}) /$ $(\mathrm{tw}-\mathrm{dw}) \times 100$. The leaves were weighed $(\mathrm{fw}-\mathrm{fresh}$ weight), and then soaked in freshly deionized water for 
$12 \mathrm{~h}$ in darkness at $5^{\circ} \mathrm{C}$ and their turgid weight (tw) was determined. The samples were then oven-dried at $80^{\circ} \mathrm{C}$ for $72 \mathrm{~h}$ and weighed (dw - dry weight) (Barrs and Weatherley 1962; Turner 1981).

Measurements of leaf water potential were taken with a psychrometer HR 33 T (WESCOR, Inc., Logan, Utah, USA), equipped with leaf sample chambers C-52 (WESCOR, Inc., Logan, Utah, USA). The leaf discs (collected from the central part of a leaf blade), $5 \mathrm{~mm}$ in diameter, were placed in C-52 chambers and left for $60 \mathrm{~min}$. The measurements were taken in the dew point mode.

Pre-dawn samples were collected at 6:00 to 7:00 a.m., while midday samples were collected at 12:00 to 1:00 p.m.

\section{Chlorophyll fluorescence measurements}

Chlorophyll fluorescence analysis during the drought and rehydration at the tillering stage was carried out using a fluorometer Handy PEA (Hansatech Ltd. Kings Lynn, UK). Data were scored after $25 \mathrm{~min}$ of leaf adaptation to darkness. $\mathrm{F}_{\mathrm{v}} / \mathrm{F}_{\mathrm{m}}$ (quantum yield of PSII) was calculated according to van Kooten and Snel (1990) as $\left(F_{m}-F_{o}\right) / F_{m}$, where $F_{o}$ and $F_{m}$ represent the minimal and maximal chlorophyll fluorescence, respectively. The excitation irradiance was $3000 \mu \mathrm{mol}$ (quanta) $\mathrm{m}^{-2} \mathrm{~s}^{-1}$ (peak at $650 \mathrm{~nm}$ ). Fluorescence was recorded during irradiation between $10 \mu \mathrm{s}$ and $1 \mathrm{~s}$. During the initial $2 \mathrm{~ms}$, the data were scored every $10 \mu$ s with a 12 bit resolution. The following parameters were calculated per excited leaf cross-section $\left(\mathrm{CS}_{\mathrm{m}}\right)$ : PI (overall performance index of PSII photochemistry), $\mathrm{DI}_{\mathrm{o}} / \mathrm{CS}_{\mathrm{m}}$ (energy amount dissipated from PSII), $\mathrm{RC} / \mathrm{CS}_{\mathrm{m}}$ (number of active reaction centers), $\mathrm{ET}_{\mathrm{o}} / \mathrm{CS}_{\mathrm{m}}$ (amount of energy used for the electron transport) and $\mathrm{TR}_{\mathrm{o}} / \mathrm{CS}_{\mathrm{m}}$ (amount of excitation energy trapped in PSII reaction centers), $\psi \mathrm{R}_{\mathrm{o}}$ (probability, at time 0 , that a trapped exciton moves an electron into the electron transport chain beyond $\mathrm{Q}_{\mathrm{A}}{ }^{-}$), $\delta \mathrm{R}_{\mathrm{O}}$ (the efficiency with which an electron can move from the reduced intersystem of electron acceptors to the PSI end electron acceptors), $\varphi R_{o}$ (the quantum yield of electron transport from $\mathrm{Q}_{\mathrm{A}}{ }^{-}$to the PSI end electron acceptors). Calculations for the parameters were based on the theory of energy flow in PSII using the JIP test (Strasser and TsimilliMichael 2001; Tsimilli-Michael and Strasser 2008; Strasser et al. 2010).

Chlorophyll fluorescence measurements of the flag leaves were performed with a fluorometer FMS 2
(Hansatech Instruments, Kings Lynn, UK). The leaves were adapted to darkness for $25 \mathrm{~min} . \mathrm{F}_{\mathrm{v}} / \mathrm{F}_{\mathrm{m}}$ (quantum yield of PSII) was calculated according to van Kooten and Snel (1990). Then, the leaves were continuously illuminated with white actinic light $\left(400 \mu \mathrm{mol} \mathrm{m}^{-2} \mathrm{~s}^{-1}\right)$. After $7 \mathrm{~min}$, the fluorescence in steady state $\left(\mathrm{F}_{\mathrm{s}}\right)$ was recorded and a second saturating pulse at $8000 \mu \mathrm{mol} \mathrm{m}{ }^{-2} \mathrm{~s}^{-1}$ was imposed to determine the maximal fluorescence in the light-adapted state $\left(\mathrm{F}_{\mathrm{m}}{ }^{\prime}\right)$. The minimal fluorescence in the light-adapted state $\left(\mathrm{F}_{\mathrm{o}}{ }^{\prime}\right)$ was determined by brief application (3 s) of low-intensity $\left(6 \mu \mathrm{mol} \mathrm{m} \mathrm{m}^{-2} \mathrm{~s}^{-1}\right)$ far-red light (730 nm). Photochemical quenching coefficient $\mathrm{q}_{\mathrm{P}}=\left(\mathrm{F}_{\mathrm{m}}{ }^{\prime}-\mathrm{F}_{\mathrm{s}}\right) /\left(\mathrm{F}_{\mathrm{m}}{ }^{\prime}-\mathrm{F}_{\mathrm{o}}{ }^{\prime}\right)$, efficiency of excitation transfer to open PSII centers $\mathrm{F}_{\mathrm{v}}{ }^{\prime} / \mathrm{F}_{\mathrm{m}}{ }^{\prime}=\left(\mathrm{F}_{\mathrm{m}}{ }^{\prime}\right.$ $\left.\mathrm{F}_{\mathrm{o}}{ }^{\prime}\right) \mathrm{F}_{\mathrm{m}}{ }^{\prime}$, PSII quantum efficiency $\Phi_{\mathrm{PSII}}=\left(\mathrm{F}_{\mathrm{m}}{ }^{\prime}-\mathrm{F}_{\mathrm{s}}\right) / \mathrm{F}_{\mathrm{m}}{ }^{\prime}$ and the electron transport rate $\mathrm{ETR}=\mathrm{PAR} \times 0.5 \times \Phi_{\mathrm{PSII}} \times$ 0.84 were calculated as in Genty et al. (1989). Nonphotochemical quenching $\mathrm{q}_{\mathrm{N}}=1-\left(\mathrm{F}_{\mathrm{m}}{ }^{\prime}-\mathrm{F}_{\mathrm{o}}{ }^{\prime}\right) /\left(\mathrm{F}_{\mathrm{m}}-\mathrm{F}_{\mathrm{o}}\right)$ was calculated according to van Kooten and Snel (1990).

Fluorescence emission spectra of red $(690 \mathrm{~nm})$ and far-red fluorescence $(740 \mathrm{~nm})$ were measured using a spectrofluorometer (Perkin-Elmer LS 50B, Norwalk, USA), according to Hura et al. (2007a). Fluorescence intensity was recorded between 650 and $800 \mathrm{~nm}$. The leaves were excited at $450 \mathrm{~nm}$. The spectral slit width was set at $10 \mathrm{~nm}$ (excitation and emission).

Fluorescence images of the leaves were made using a PSI Fluorcam 700MF chlorophyll fluorescence imaging system (PSI, Brno, Czech Republic), as described by Nedbal et al. (2000). Fluorcam v. 3.5 software was used to control the imaging system and to process the images.

Leaf photosynthetic activity

Leaf gas exchange measurements were performed at ambient temperature $\left(25 \pm 2{ }^{\circ} \mathrm{C}\right)$ and ambient relative humidity $(40 \pm 5 \%)$ in the greenhouse conditions, on fully expanded leaves, using an infrared gas analyzer (CID; CI $301 \mathrm{CO}_{2}$; Inc. Vancouver, Washington, USA), operated within an open system with a leaf chamber. The net photosynthesis $\left(\mathrm{P}_{\mathrm{N}}\right)$, transpiration rate $(\mathrm{E})$ and stomatal conductance $(\mathrm{gs})$ were determined between 11:00 a.m. and 1:00 p.m. under air flow $200 \mathrm{~mL} \mathrm{~min}^{-1}$, the saturating PPFD of $1100 \mu \mathrm{mol}$ (photons) $\mathrm{m}^{-2} \mathrm{~s}^{-1}$ (Hura et al. 2006, 2007b) provided by LED light module (CI-301LA, CID, Camas, WA, USA), and at air $\mathrm{CO}_{2}$ concentration of $380 \mathrm{ppm}$, provided by $\mathrm{CO}_{2}$ control unit (CI-301 AD, CID, Camas, WA, USA). 
Pigment content

Chlorophyll and carotenoids content were analyzed spectrophotometrically (Ultrospec II, Biochrom, Cambridge, England), after extraction in $95 \%$ ethanol. The concentration of chlorophyll and carotenoids was then calculated according to Lichtenthaler and Wellburn (1983).

Histochemical identification of superoxide radical

Dye-based identification of superoxide radical in the leaves was done according to Doke and Ohashi (1988). The leaves were infiltrated in darkness for $15 \mathrm{~min}$ under the pressure of $0.8 \mathrm{MPa}$ with a solution containing $0.5 \%(w / v)$ nitroblue tetrazolium (NBT), $10 \mathrm{mM}$ potassium phosphate buffer $\mathrm{pH} 7.0$, and $0.005 \%(w / v)$ Triton X-100, and then exposed to light for $15 \mathrm{~min}$. The leaves were rinsed several times with hot ethanol (96\%) to remove chlorophyll from the plant tissues. The colored spots (dark blue) of superoxide radical accumulation in the leaves were scanned (CanoScan, Lide 110). Staining was carried out on the seventh day of the rehydration.

\section{Hydrogen peroxide content}

Histochemical detection of hydrogen peroxide was performed according to Thordal-Christensen et al. (1997). The leaves were infiltrated in darkness for $15 \mathrm{~min}$ under the pressure of $0.8 \mathrm{MPa}$ in 3,3'-diaminobenzidine (DAB) solution. DAB aqueous solution was prepared in the ratio $1 \mathrm{mg}$ DAB: $1 \mathrm{~mL}$ $\mathrm{H}_{2} \mathrm{O}$, and $\mathrm{pH}$ was adjusted to 3.8 with $0.1 \mathrm{M} \mathrm{HCl}$. To remove chlorophyll, the leaves were rinsed with hot $\left(60{ }^{\circ} \mathrm{C}\right)$ ethanol $(95 \%)$. The colored spots, indicating $\mathrm{H}_{2} \mathrm{O}_{2}$ accumulation in the leaves, were scanned.

Hydrogen peroxide content was analyzed according to Ishikawa et al. (1993). The leaves were homogenized in $1.4 \mathrm{~mL}$ of the extraction buffer containing $50 \mathrm{mM}$ potassium phosphate buffer $\mathrm{pH} 7.5,5 \%$ trichloroacetic acid, $1 \mathrm{mM}$ EDTA, and $1 \% \mathrm{w} / v$ polyvinylpyrrolidone. The reaction mixture consisted of $2.5 \mathrm{~mL}$ of $1.25 \mathrm{mM}$ homovanillic acid, $2.5 \mu \mathrm{L}$ of horseradish peroxidase $\left(1380 \mathrm{U} \mathrm{mg}^{-1}\right)$ and $20 \mu \mathrm{L}$ of the buffered extract. $\mathrm{H}_{2} \mathrm{O}_{2}$ content was analyzed with a spectrofluorometer (Perkin-Elmer LS 50B, Norwalk, CT, USA). The reaction mixtures were excited at $315 \mathrm{~nm}$ and fluorescence emission was detected at $400-450 \mathrm{~nm}$.
The excitation and emission slit width of the monochromators was adjusted to $10 \mathrm{~nm}$.

Total catalase (CAT) activity

Catalase activity was assessed according to Aebi (1984). Plant material (150-200 mg of fresh weight) was homogenized in the extraction buffer $(50 \mathrm{mM}$ potassium phosphate buffer $\mathrm{pH} 7.5,1 \mathrm{mM}$ EDTA) at $4{ }^{\circ} \mathrm{C}$. Plant extract $(100 \mu \mathrm{L})$ was added to the reaction mixture consisting of $0.3 \mathrm{~mL}$ of $30 \% \mathrm{H}_{2} \mathrm{O}_{2}$ in $50 \mathrm{mM}$ potassium phosphate buffer $\mathrm{pH} 7.8$ and $1 \mathrm{mM}$ EDTA. Absorbance was analyzed at $240 \mathrm{~nm}$. The enzyme activity was recalculated, assuming that absorbance drop of about 0.0145 corresponds to the degradation of $1 \mu \mathrm{mol}$ of $\mathrm{H}_{2} \mathrm{O}_{2}$ within 1 min per $\mathrm{g}$ of protein.

Total peroxidase activity (POX)

The leaves (150-200 mg of fresh weight) were homogenized in the extraction buffer $(50 \mathrm{mM}$ potassium phosphate buffer $\mathrm{pH} 7.0,1 \mathrm{mM}$ EDTA) at $4{ }^{\circ} \mathrm{C}$. The reaction mixture contained $2 \mathrm{~mL}$ of $50 \mathrm{mM}$ potassium phosphate buffer ( $\mathrm{pH}$ 7.8), $1 \mathrm{mM}$ EDTA, $12 \mu \mathrm{L}$ of pphenylenediamine, $12 \mu \mathrm{L}$ of $30 \% \mathrm{H}_{2} \mathrm{O}_{2}$ and $15 \mu \mathrm{L}$ of the plant extract. Absorbance was measured at $460 \mathrm{~nm}$. According to Bergmeyer (1965), increasing absorbance correlates with an accumulation of oxidized products of p-phenyldiamine in $\mathrm{H}_{2} \mathrm{O}_{2}$ presence. One unit of $\mathrm{POX}$ activity was defined as an increase in absorbance (0.01 $\Delta \mathrm{A}_{460}=1 \mathrm{EU}$ ) per $1 \mathrm{~min}$ per $\mathrm{g}$ of protein.

\section{Excitation spectra of blue fluorescence}

Blue fluorescence excitation spectra were recorded using Perkin-Elmer LS 50B spectrofluorometer, according to Hura et al. (2006). Leaf samples were excited at 250-400 $\mathrm{nm}$ and blue fluorescence emission was observed at $440 \mathrm{~nm}$. The excitation and emission monochromator slit width was adjusted to $10 \mathrm{~nm}$.

\section{Statistical analysis}

Statistical analysis was carried out using Statistica v. 9.0 (Statsoft Inc.). Analysis of variance was used to determine the main effects of treatments on the physiological parameters within each studied cultivar. Duncan's multiple range test at 0.05 probability level was chosen to determine the significance of differences among the 
treatment means. Correlations between measured parameters were tested at a probability of $P<0.05$.

\section{Results}

Soil water content and plant water relations during drought and rehydration

Soil water content (SWC) under optimal plant growth conditions (Fig. 1a) and during R1 and R3 rehydration
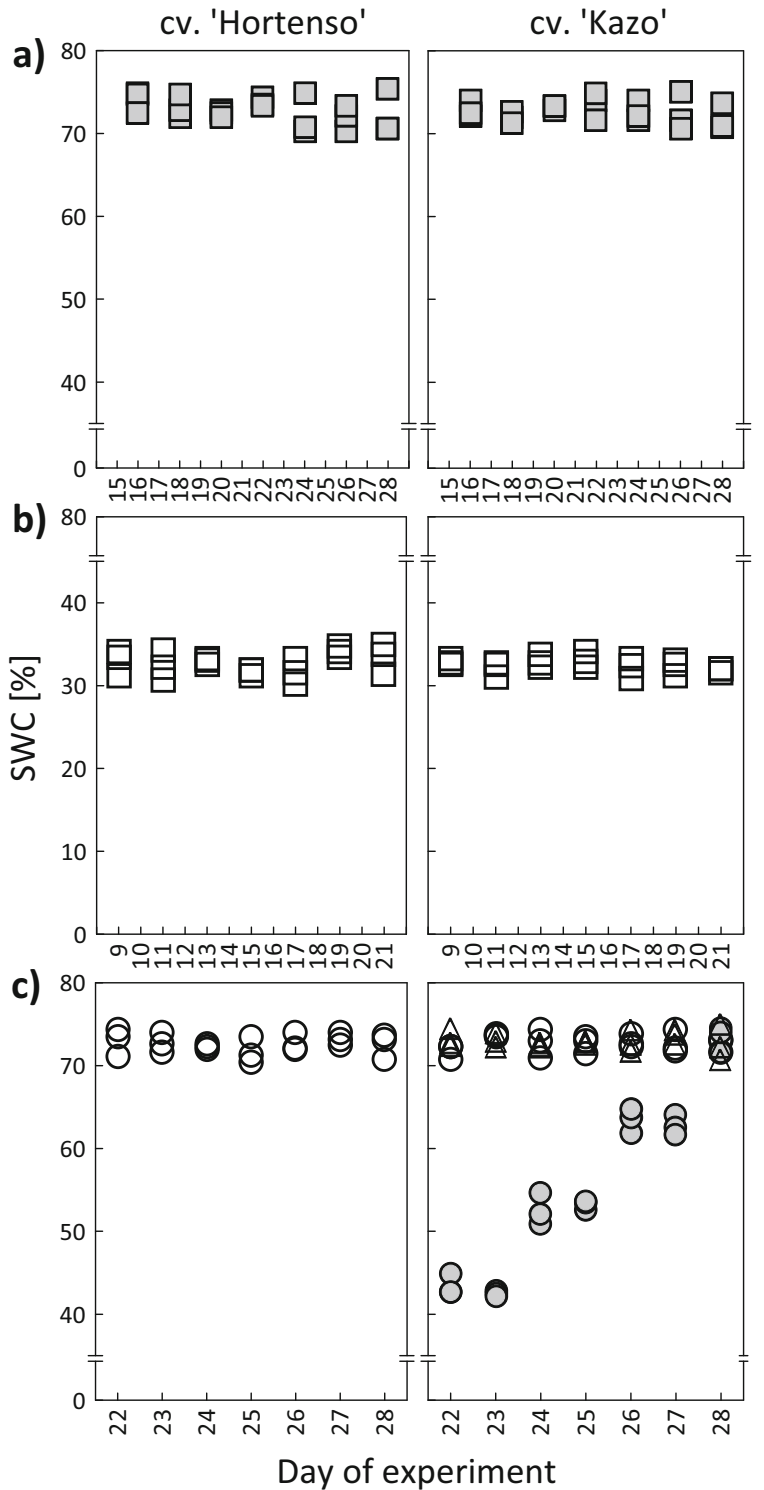

Fig. 1 Soil water content (SWC) in the pots for control (a; $\square$ ) drought $(\mathbf{b} ; \square)$, and rehydration (c): R1 (०), R2 (O), R3 ( $\triangle$ )
(Fig. 1c) ranged between 70 and $75 \%$, and in the drought period it amounted to 30-35\% (Fig. 1b). For the R2 variant, SWC ranges were 40-45\%, $50-55 \%, 60-65 \%$ and $70-75 \%$ during the rehydration period (Fig. 1c).

Following 3 weeks of drought, the plants of both triticale cultivars either growing in optimum water soil conditions or exposed to the rehydration showed similar leaf water content (Fig. 2). After 3 weeks of drought, the leaf relative water content (RWC) in 'Hortenso' and 'Kazo' cultivars reached $65 \%$ (RWC) (Fig. 2a), and leaf water potential was about $-2.2 \mathrm{MPa}$ (Fig. 2b). Gradual restoration of soil water content in $\mathrm{R} 2$ variant was reflected in the gradual increase in leaf water content in
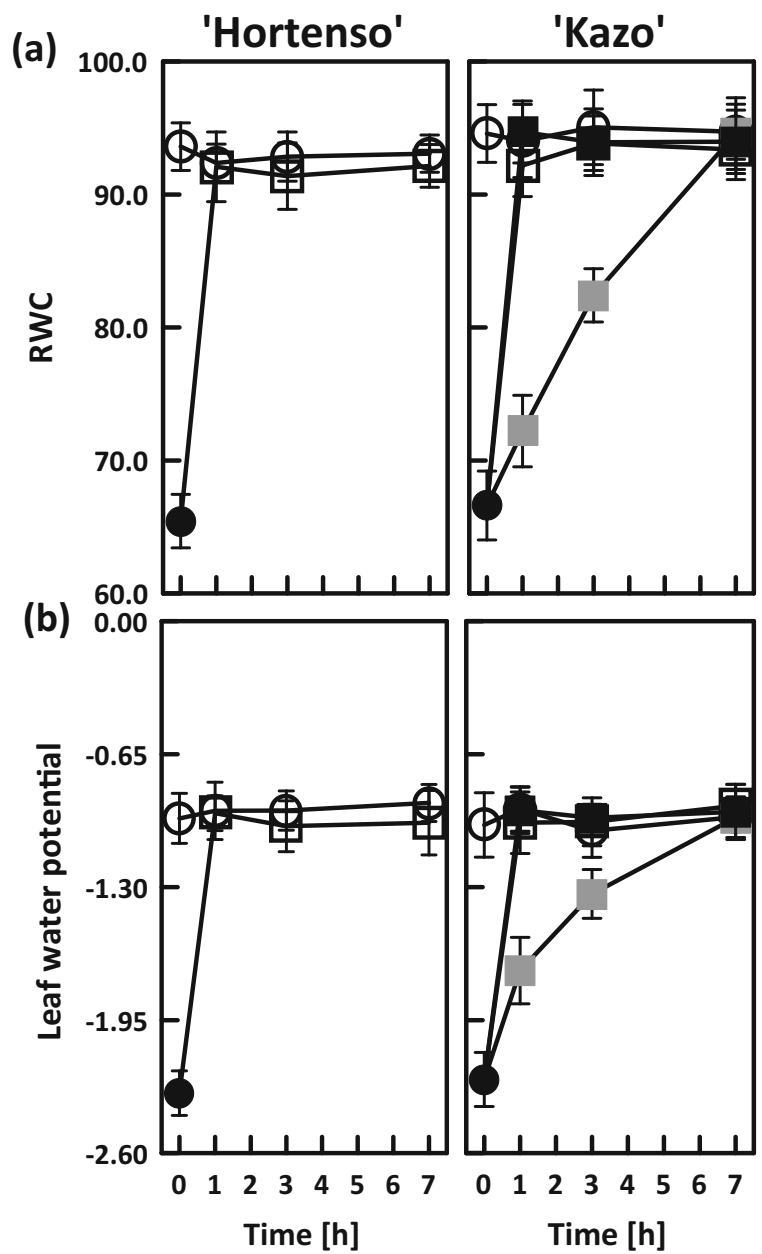

Fig. 2 Relative water content (RWC, [\%]) (a) and leaf water potential (b, [MPa]) for fully-recovered 'Hortenso' cultivar and not fully-recovered 'Kazo' cultivar. The analyses were performed $1,3$ and 7 days after rehydration. Control-( $(\circ)$, drought-( $\bullet)$, rehydration: R1-(口), R2-( $(\square), \mathrm{R} 3-(\square)$. Means $\pm \mathrm{SE}$ ( $n=10$ for RWC; $n=$ 7 for leaf water potential) 
the not fully-recovered cv. 'Kazo'. After $24 \mathrm{~h}$ of R1 and R3 rehydration, leaf water content of both cultivars was the same as in the control plants (about $95 \%$ RWC and $-0.90 \mathrm{MPa})$.

Reactive oxygen species and antioxidant enzyme activity

The plants exposed to R1 and R3 treatments showed high content of superoxide radical after 7 days of the rehydration as compared to R2 treatment (Fig. 3).

The leaves of fully-recovered cv. 'Hortenso' showed a decrease in $\mathrm{H}_{2} \mathrm{O}_{2}$ content down to the control level during R1 rehydration (Fig. 4a and d). Low content of hydrogen peroxide in this cultivar was accompanied by high activity of catalase (Fig. 4b) and peroxidase (Fig. 4c). In the not fully-recovered cv. 'Kazo', increased activity of catalase and peroxidase and low $\mathrm{H}_{2} \mathrm{O}_{2}$ content were observed only during $\mathrm{R} 2$ treatment.

Intensity of blue fluorescence $\left(\mathrm{F}_{440}\right)$ excitation

In the fully-recovered cv. 'Hortenso', a significant increase in the intensity of blue fluorescence excitation was noticed on the last day of drought and after 7 days of R1 treatment (Fig. 5). In the not fully-recovered 'Kazo' plants, large and statistically significant increase in the intensity of blue fluorescence excitation in relation to the control and drought variant was observed only for $\mathrm{R} 2$ treatment.

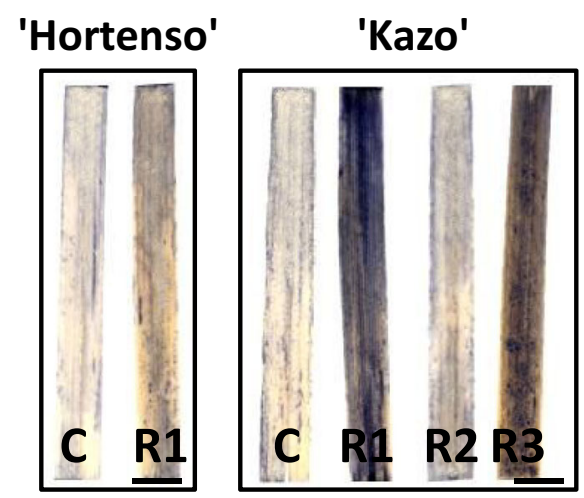

Fig. 3 Histochemical detection of superoxide radical with the use of nitroblue tetrazolium (NBT) performed after 7 days of rehydration for fully-recovered 'Hortenso' cultivar and not fully-recovered 'Kazo' cultivar (C -control plants, R1/R2/R3-rehydration). Black bars $=1 \mathrm{~cm}$
Activity of the photosynthetic apparatus in the vegetative growth phase

Leaf photosynthetic activity was fully restored after 7 days of rehydration in 'Hortenso' cultivar exposed to $\mathrm{R} 1$ treatment and in 'Kazo' plants subjected to R2 scheme (Fig. 6). After 7 days of R1 rehydration, the net photosynthesis rate (Pn) (Fig. 6a), transpiration (E) (Fig. 6b) and stomatal conductance (gs) (Fig. 6c) in the not fully-recovered cultivar were significantly lower than those recorded in the drought-exposed plants. After 7 days of R3 rehydration, gas exchange intensity was at the same level as in the droughtexposed plants.

After 7 days of R2 rehydration, fluorescence parameters in the leaves of not fully-recovered cultivar were the same as in the control plants (Table 1). Further decline in the activity of the photosynthetic apparatus, as compared with drought-exposed plants, was observed during R1 rehydration. It was manifested by significantly lower (PI, $\mathrm{ET}_{\mathrm{o}} / \mathrm{CS}_{\mathrm{m}}, \mathrm{RC} / \mathrm{CS}_{\mathrm{m}}, \psi \mathrm{R}_{\mathrm{o}}, \delta \mathrm{R}_{\mathrm{o}}, \varphi \mathrm{R}_{\mathrm{o}}$ ) or higher $\left(\mathrm{DI}_{\mathrm{o}} / \mathrm{CS}_{\mathrm{m}}\right)$ chlorophyll fluorescence parameters. In the fully-recovered 'Hortenso' cultivar, chlorophyll fluorescence parameters after 7 days of R1 treatment were equal to the control (Table 1).

Statistically significant correlations were observed between chlorophyll fluorescence parameters and hydrogen peroxide level (Fig. 7). High amounts of both the energy used for electron transport $\left(\mathrm{ET}_{\mathrm{o}} / \mathrm{CS}_{\mathrm{m}}\right)$ (Fig. 7a) and the excitation energy trapped in PSII reaction centers $\left(\mathrm{TR}_{\mathrm{o}} / \mathrm{CS}_{\mathrm{m}}\right)$ (Fig. $\left.7 \mathrm{~b}\right)$ correlated with increased content of $\mathrm{H}_{2} \mathrm{O}_{2}$. Additionally, higher content of $\mathrm{H}_{2} \mathrm{O}_{2}$ corresponded to a reduced probability that a trapped exciton moves an electron into the electron transport chain beyond $\mathrm{Q}_{\mathrm{A}}{ }^{-}\left(\psi \mathrm{R}_{\mathrm{o}}\right)$ (Fig. 7c), the efficiency with which an electron can move from the reduced intersystem of electron acceptors to the PSI end electron acceptors $\left(\delta R_{\mathrm{o}}\right)($ Fig. $7 \mathrm{~d})$, and the quantum yield of electron transport from $\mathrm{Q}_{\mathrm{A}}{ }^{-}$to the PSI end electron acceptors $(\varphi$ Ro) (Fig. 7e).

An analysis of red $\left(\mathrm{F}_{690}\right)$ and far-red $\left(\mathrm{F}_{740}\right)$ fluorescence emission spectra revealed that in the not fullyrecovered plants exposed to 7 days of R2 rehydration low intensity of red fluorescence emission (equal to control) (Fig. 8a) was accompanied by high intensity of far-red fluorescence emission (Fig. 8b and c). The not fully-recovered plants exposed to R1 treatment 


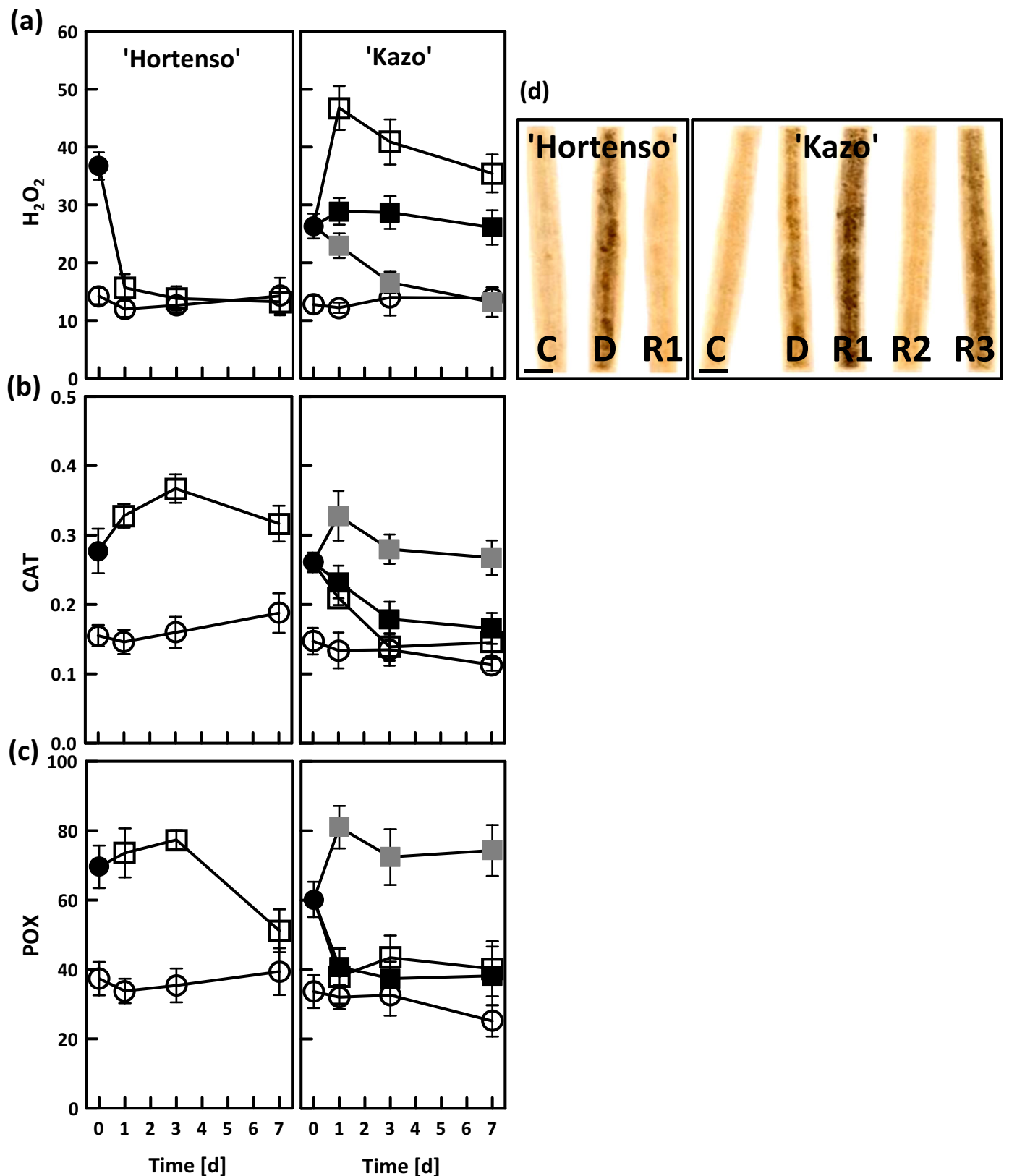

Fig. 4 The content of hydrogen peroxide $\left(\mathbf{a},\left[\mu \mathrm{mol} \mathrm{H}_{2} \mathrm{O}_{2} \mathrm{~g}^{-1}\right.\right.$ DW]), activity of catalase (CAT, $\left[\mu \mathrm{mol} \mathrm{H}_{2} \mathrm{O}_{2} \mathrm{~min}^{-1} \mathrm{mg}^{-1}\right.$ proteins]) (b) and total activity of peroxidase (POX, [units ${ }^{-1} \mathrm{~min}^{-1} \mathrm{mg}^{-1}$ proteins]) (c) for fully-recovered 'Hortenso' cultivar and not fully-recovered 'Kazo' cultivar. The analyses were performed 1, 3 and 7 days after rehydration. Control-( $(\circ)$, drought-

$(\bullet)$, rehydration: R1-( $\square)$, R2-( $\square$ ), R3-(घ). Means \pm SE ( $n=10$ for $\mathrm{H}_{2} \mathrm{O}_{2} ; n=7$ for CAT and POX). d Histochemical detection of $\mathrm{H}_{2} \mathrm{O}_{2}$ with the use of 3,3'-diaminobenzidine (DAB), performed after 7 days of rehydration for fully-recovered 'Hortenso' cultivar and not fully-recovered 'Kazo' cultivar (C-control plants, D-drought, $\mathrm{R} 1 / \mathrm{R} 2 / \mathrm{R} 3$-rehydration). Black bars $=1 \mathrm{~cm}$

responded with a significant increase in the intensity of red fluorescence emission, while $\mathrm{F}_{740}$ fluorescence was not significantly different from either the control or drought-exposed plants. Intensity of $\mathrm{F}_{740}$ emission during R3 rehydration was similar to that

observed for control and drought-exposed plants. In contrast, the intensity of $\mathrm{F}_{690}$ emission was significantly higher than that of the control but did not differ significantly from that observed in drought-exposed plants. 


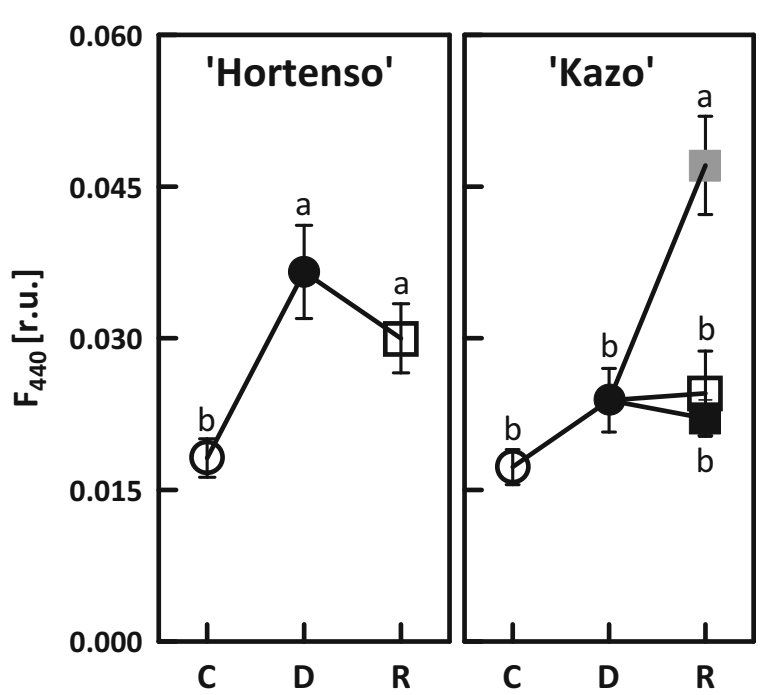

Fig. 5 Intensity of blue fluorescence $\left(\mathrm{F}_{440}\right)$ excitation for fullyrecovered 'Hortenso' cultivar and not fully-recovered 'Kazo' cultivar. The analyses were performed after 3 weeks of drought and 7 days of rehydration. Control $-(\mathrm{C}, \circ)$, drought- $(\mathrm{D}, \bullet)$, rehydration (R): R1-(口), R2-( ), R3-(匹). Duncan's test at 0.05 probability level was performed in order to determine the significance of differences between treatment means. Means indicated with the same letters within cultivar were not significantly different. Means \pm SE $(n=10)$

Fluorescence imaging of leaf segments, in which gas exchange and chlorophyll fluorescence were analyzed, indicated increased intensity of red fluorescence emission in 'Hortenso' and 'Kazo' cultivars following 3 weeks of drought (Fig. 8d). Higher intensity of red fluorescence emission in the drought-exposed plants was observed for R1 rehydration. In R2 variant, red fluorescence emission was similar to the control, while after 7 days of R3 treatment it was similar to that observed for drought-exposed plants.

Three weeks of soil drought resulted in a decrease of chlorophyll and carotenoid content in both cultivars (Table 2). After 7 days of R1 rehydration in the fully-

Fig. 6 Net photosynthetic activity $\left(\mathrm{Pn},\left[\mu \mathrm{mol}\left(\mathrm{CO}_{2}\right) \mathrm{m}^{-2} \mathrm{~s}^{-1}\right]\right)$ (a), transpiration activity $\left(\mathrm{E},\left[\mathrm{mmol}\left(\mathrm{H}_{2} \mathrm{O}\right) \mathrm{m}^{-2} \mathrm{~s}^{-1}\right]\right)(\mathbf{b})$ and stomatal conductance (gs, $\left.\left[\mathrm{mmol}\left(\mathrm{CO}_{2}\right) \mathrm{m}^{-2} \mathrm{~s}^{-1}\right]\right)$ (c) for fully-recovered 'Hortenso' cultivar and not fully-recovered 'Kazo' cultivar. The analyses were performed after 3 weeks of drought and 7 days of rehydration. Control $-(\mathrm{C}, \mathrm{O})$, drought-(D, •), rehydration $(\mathrm{R})$ : R1(口), R2-( ), R3-(ロ). Duncan's test at 0.05 probability level was performed in order to determine the significance of differences between treatment means. Means indicated with the same letters within cultivar were not significantly different. Means $\pm \operatorname{SE}(n=10)$

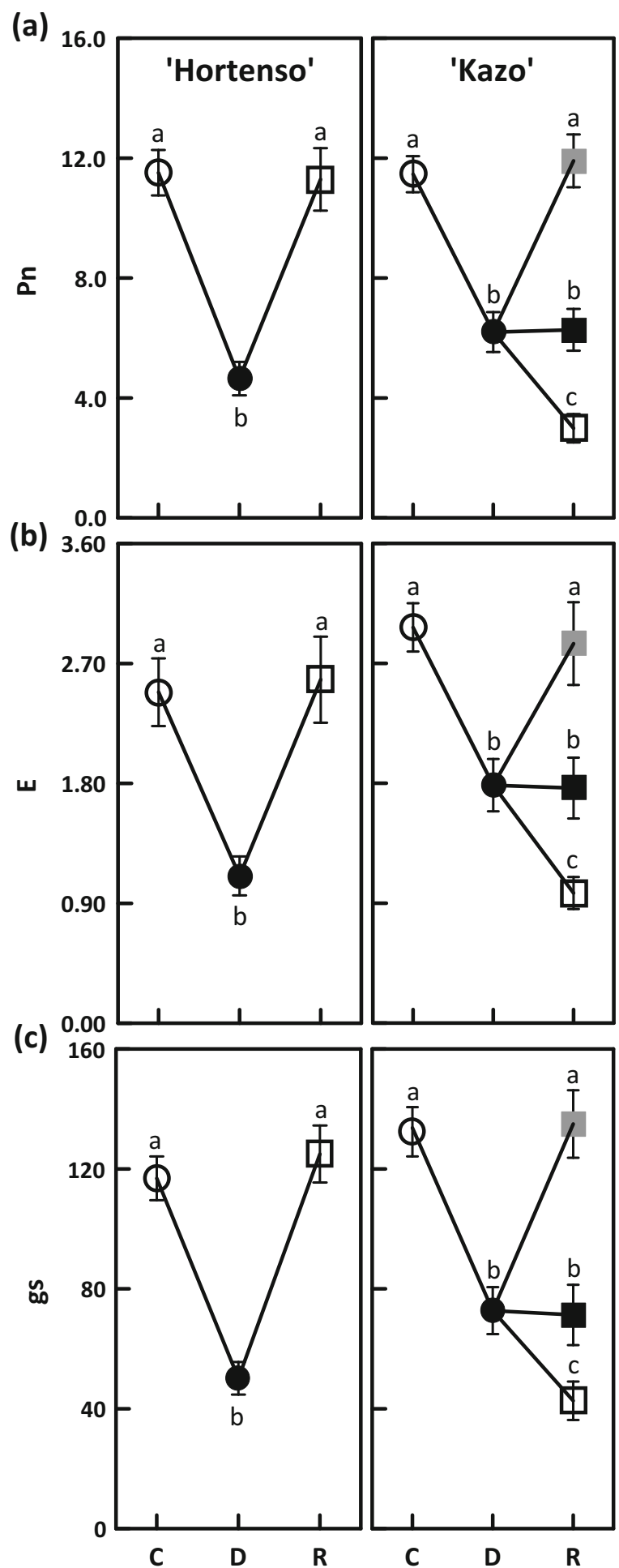

recovered cv. 'Hortenso' and after 7 days of R1, R2 or $\mathrm{R} 3$ rehydration in the not fully-recovered cv. 'Kazo' the 


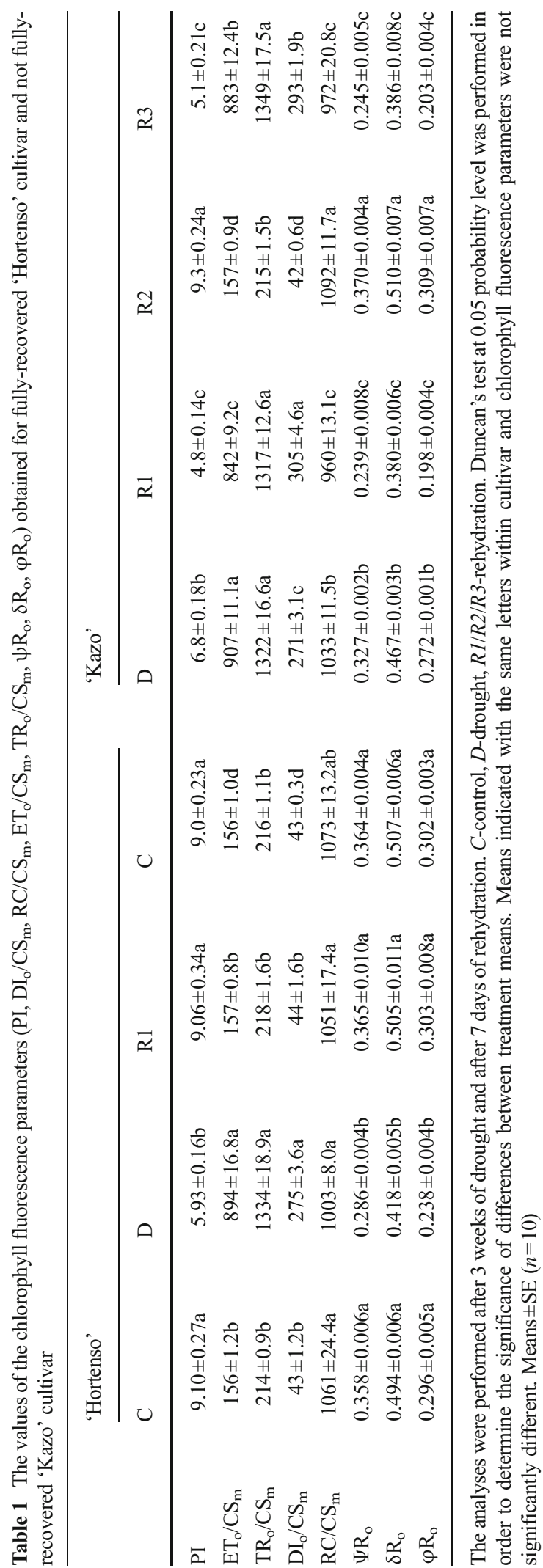

content of chlorophyll and carotenoids did not differ significantly from the controls.

Activity of the photosynthetic apparatus in flag leaf and grain yield analysis

The analyses carried out after 42 days of rehydration showed no significant differences in flag leaf water content, pigment content, hydrogen peroxide level, and the activity of antioxidant enzymes (Table 3 ). The leaves of not fully-recovered cv. 'Kazo', rehydrated using R1 and R3 schemes, still showed low photosynthetic activity (Fig. 9a), accompanied by lack of differences concerning transpiration (Fig. 9b) and stomatal conductance (Fig. 9c) when compared to the control plants. However, Pn values in the not fullyrecovered cultivar were significantly higher for R3 than for R1 (Fig. 9a). It was also observed that R1 and R3 rehydration triggered permanent reduction in the activity of flag leaf photosynthetic apparatus. In comparison with the control, R1 treatment resulted in a significant drop in the maximum photochemical efficiency of PSII $\left(\mathrm{F}_{\mathrm{v}} / \mathrm{F}_{\mathrm{m}}\right)$ (Fig. 10a), a decrease in effective excitation energy capture by PSII centers and trapping of light quanta by PSII antennae $\left(\mathrm{F}_{\mathrm{v}}{ }^{\prime} / \mathrm{F}_{\mathrm{m}}{ }^{\prime}\right)$ (Fig. $\left.10 \mathrm{~b}\right)$, a reduction in the PSII quantum efficiency $\left(\Phi_{\text {PSII }}\right)$ (Fig. 10c), less effective transfer of excitation energy towards further photochemical reactions $\left(\mathrm{q}_{\mathrm{P}}\right)$ (Fig. 10d), an increase in energy dissipation as heat $\left(\mathrm{q}_{\mathrm{N}}\right)$ (Fig. 10e), and lower electron transport rate (ETR) (Fig. 10f).

Flag leaves of the not fully-recovered cv. 'Kazo' exposed to R2 rehydration and subjected to an increasing number of point excitations (from 1 to 10) with the light of $450 \mathrm{~nm}$, emitted less intense red fluorescence (Fig. 10g) but more intense far-red fluorescence (Fig. 10h). During R1 treatment of the same cultivar, higher number of excitation events corresponded to more intense $\mathrm{F}_{690}$ emission, while the intensity of $\mathrm{F}_{740}$ emission remained unchanged. In contrast, R3 rehydration resulted in a slight increase in the intensity of both types of fluorescence with growing number of excitation events.

No significant differences in grain yield were found for individual rehydration treatments in cv. 'Hortenso' (Fig. 11). In not fully-recovered 'Kazo' plants, grain yield was the same as in control following R2 treatment 


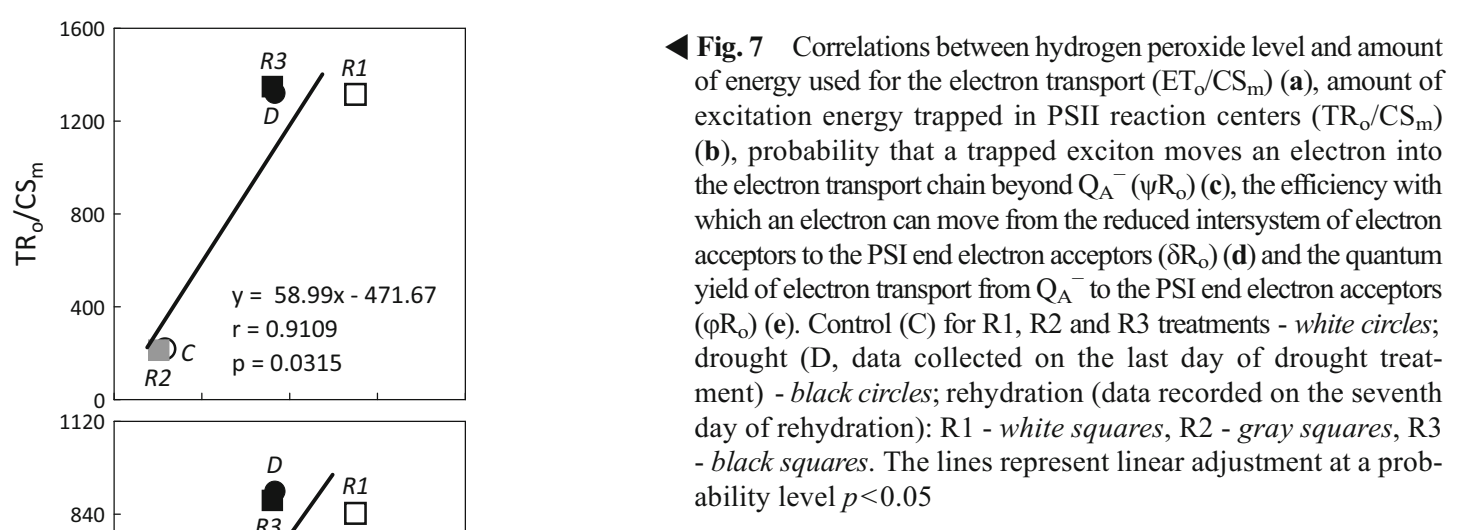

but it was significantly lower than in control for the other two treatments.

\section{Discussion}

So far, numerous papers have been published on different mechanisms of plant acclimation to soil drought and on their role in the selection of cultivars or genotypes resistant to soil water deficit (Flexas et al. 1999, 2006; Escalona et al. 2000; Flexas and Medrano 2002; Hura et al. 2007a, 2009a, b, c, 2011, 2012; Grzesiak et al. 2010; Rollins et al. 2013; Nolf et al. 2014; Borrell et al. 2014). However, very few studies investigated the problem of adverse functional changes brought about by the rehydration stage (Oliver et al. 1998; Hura et al. 2009a). In mosses and lichens, characterized by high tolerance to desiccation, rehydration stage is accompanied by hydrogen peroxide burst that may be caused by increased activity of extracellular peroxidases (Mayaba et al. 2002) and light (Proctor and Smirnoff 2000). It is well-known that an increased level of hydrogen peroxide in the plant cells is, on the one hand, a biochemical indicator of stress that can damage the plant cell structural elements and disturb its functioning (Mittler 2002), and on the other hand, it is an important signal transduction factor controlling the expression of genes involved in adaptive mechanisms activated by environmental stressors (Neill et al. 2002; Apel and Hirt 2004).

In our study, the rapid rehydration (R1) that, similarly to drought, triggered additional accumulation of $\mathrm{H}_{2} \mathrm{O}_{2}$ in the leaves of not fully-recovered triticale cultivar may initiate may initiate permanent and adverse changes in plants metabolism (Fig. 4a and d). However, it should be 

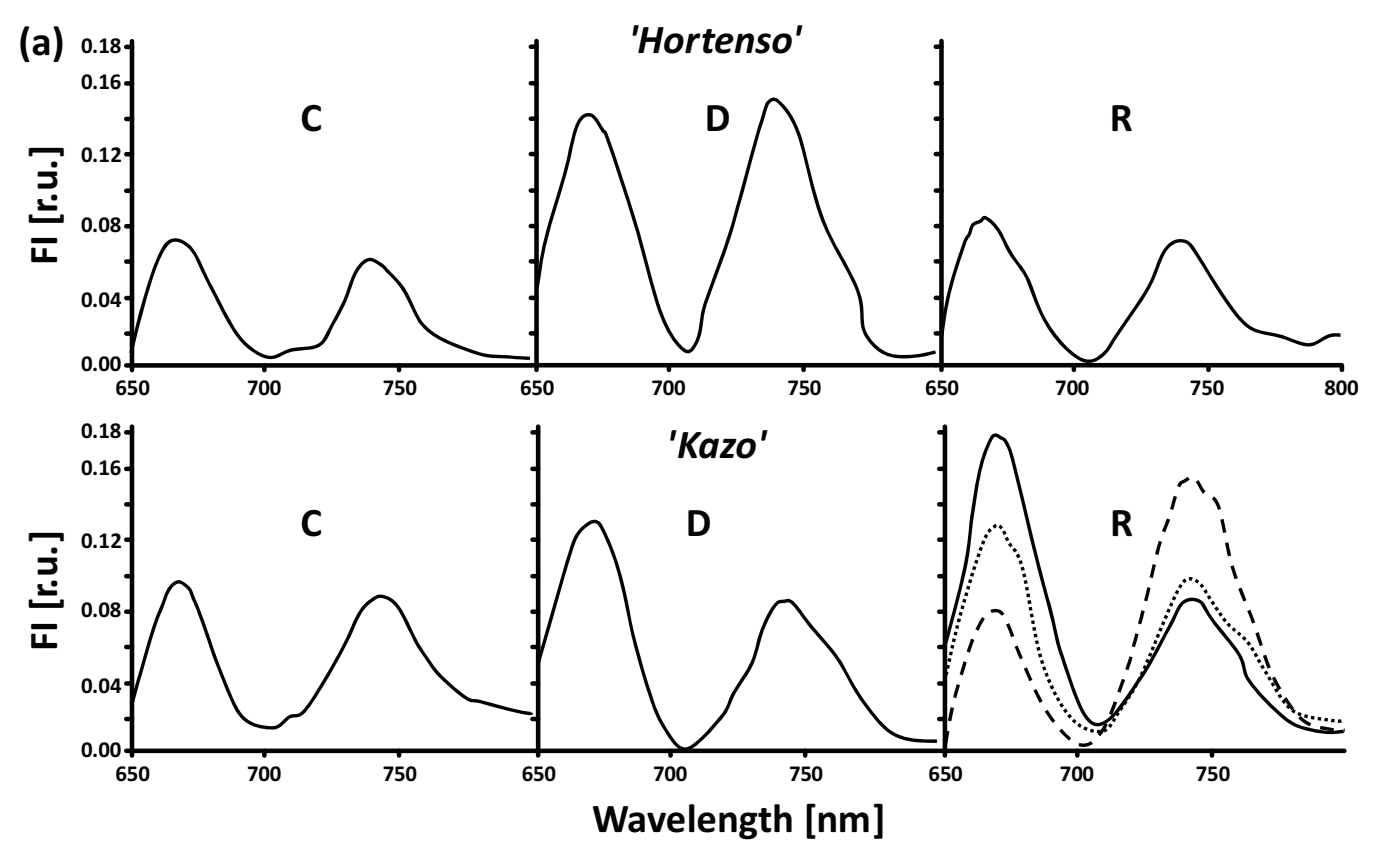

(b)

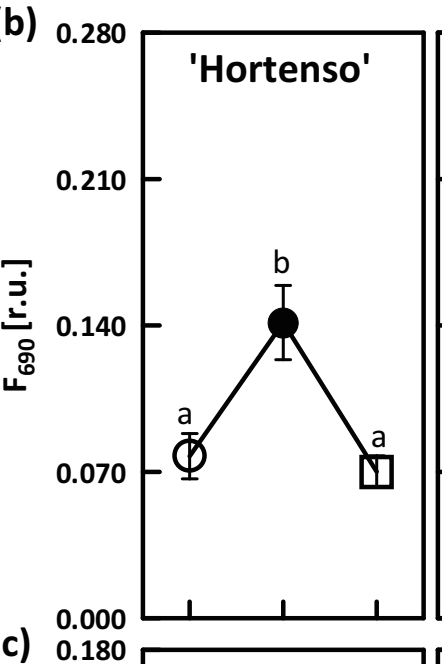

(c)
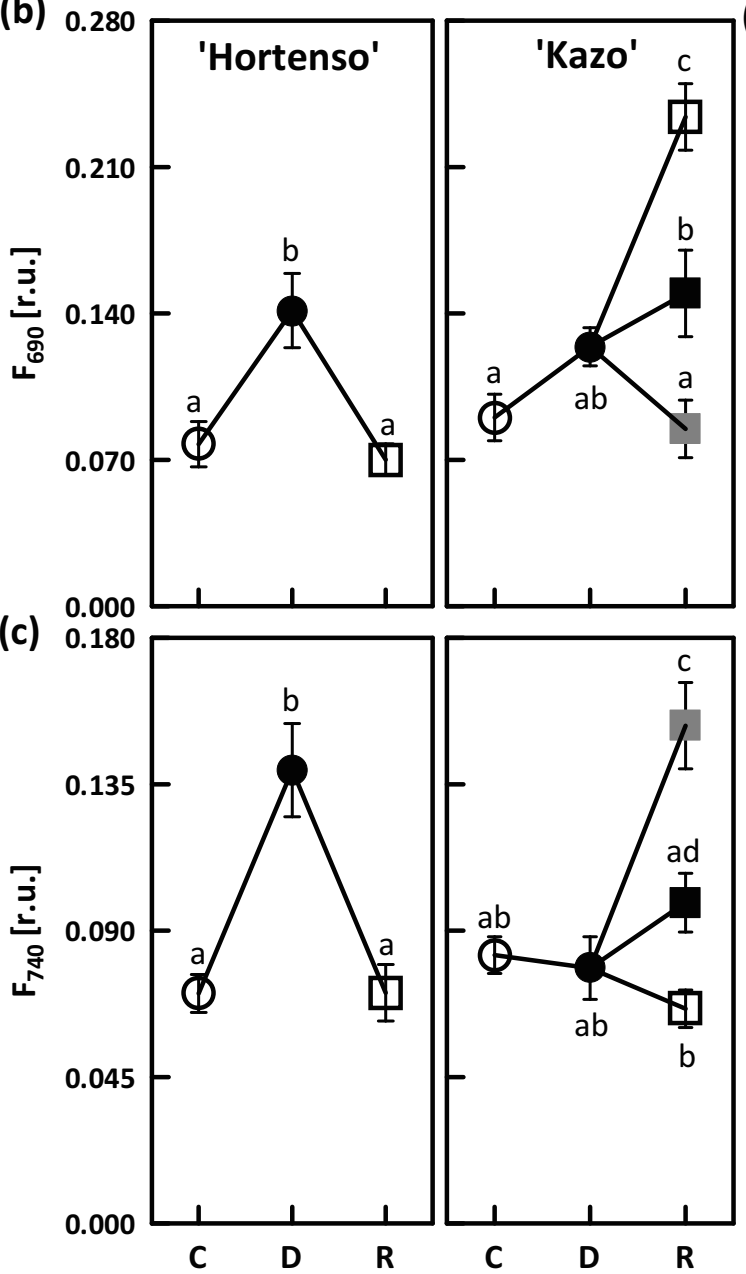

(d)

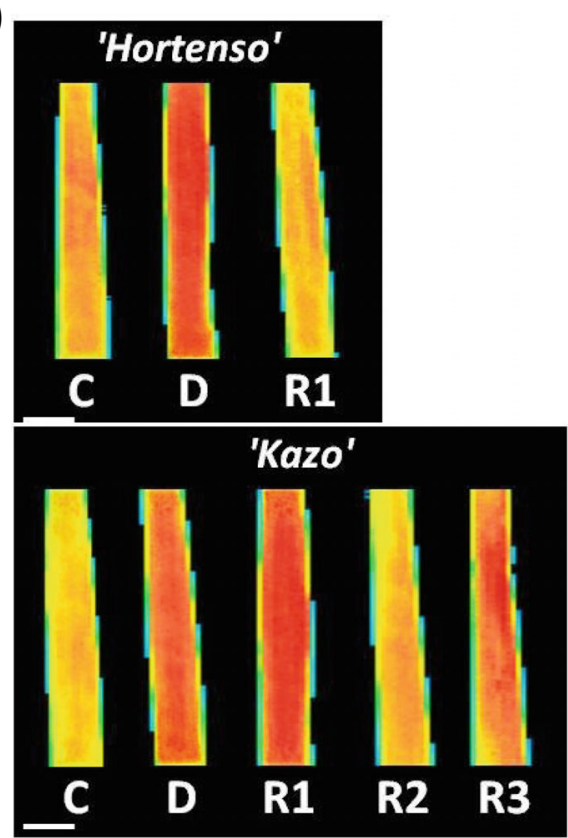


4 Fig. 8 a Exemplary emission spectra of red fluorescence and farred fluorescence performed for the control plants (C) after 3 weeks of drought (D) and 7 days of rehydration (R) for fully-recovered 'Hortenso' cultivar and not fully-recovered 'Kazo' cultivar. C, D, $\mathrm{R} 1$ - solid line, R2 - dashed line, R3 - dotted line. $\mathbf{b}$-c Intensity of red fluorescence $\left(\mathrm{F}_{690}\right)$ and far-red fluorescence $\left(\mathrm{F}_{740}\right)$ emission for fully-recovered 'Hortenso' cultivar and not fully-recovered 'Kazo' cultivar. The analyses were performed after 3 weeks of drought and 7 days of rehydration. Control -(C, o), drought-(D, •), rehydration (R): R1-(口), R2-( $\square$, R3-(匹). Duncan's test at 0.05 probability level was performed in order to determine the significance of differences between treatment means. Means indicated with the same letters within cultivar were not significantly different. Means \pm SE $(n=10)$. d Fluorescence imaging of leaf fragments for fully-recovered 'Hortenso' cultivar and not fully-recovered 'Kazo' cultivar. C-control, D-drought, R1/R2/R3-rehydration. White bars $=1 \mathrm{~cm}$

pointed out that the increase in $\mathrm{H}_{2} \mathrm{O}_{2}$ content could also correspond to the cumulative and lag response to soil drought.

The photosynthetic apparatus is an important source of ROS overproduction under environmental stresses (Asada 2006). Rapid increase in $\mathrm{H}_{2} \mathrm{O}_{2}$ content observed for R1 treatment could be due to low efficiency of excess excitation energy dissipation through the photosynthetic apparatus. In the not fully-recovered cultivar, R1 treatment resulted in increased amount of energy used for electron transport $\left(\mathrm{ET}_{\mathrm{o}} / \mathrm{CS}_{\mathrm{m}}\right)$ and higher amount of excitation energy trapped in PSII reaction centers $\left(\mathrm{TR}_{\mathrm{o}} / \mathrm{CS}_{\mathrm{m}}\right)$. Other effects of R1 treatment included low probability that a trapped exciton moves an electron into the electron transport chain beyond $\mathrm{Q}_{\mathrm{A}}{ }^{-}\left(\psi \mathrm{R}_{\mathrm{o}}\right)$, low efficiency with which an electron can move from the reduced intersystem electron acceptors to the PSI end electron acceptors $\left(\delta R_{\mathrm{o}}\right)$, and reduced quantum yield of electron transport from $\mathrm{Q}_{\mathrm{A}}{ }^{-}$to the PSI end electron acceptors $\left(\varphi \mathrm{R}_{\mathrm{o}}\right)$ (Table 1). Reduction in chlorophyll fluorescence parameters $\left(\psi \mathrm{R}_{\mathrm{o}}, \delta \mathrm{R}_{\mathrm{o}}, \varphi \mathrm{R}_{\mathrm{o}}\right)$ during $\mathrm{R} 1$ rehydration may indicate electron transfer from plastoquinone $\mathrm{Q}_{\mathrm{A}}$ to oxygen molecules. The above mentioned statements were supported by statistically significant correlations between chlorophyll fluorescence parameters $\left(\mathrm{TR}_{\mathrm{o}} / \mathrm{CS}_{\mathrm{m}}, \mathrm{ET}_{\mathrm{o}} / \mathrm{CS}_{\mathrm{m}}, \psi \mathrm{R}_{\mathrm{o}}, \delta \mathrm{R}_{\mathrm{o}}, \varphi \mathrm{R}_{\mathrm{o}}\right)$ and the content of hydrogen peroxide (Fig. 7). Takahashi et al. (1988) showed that in PSII, in the places of plastoquinone $\mathrm{Q}_{\mathrm{A}}$ and $\mathrm{Q}_{\mathrm{B}}$ activity, electron leak may occur, accompanied by a reduction of molecular oxygen to superoxide radical, further dismutated to $\mathrm{H}_{2} \mathrm{O}_{2}$. Another possible source of ROS generation during R1 could be PSI, where overloading of the electron transport chain (ETC) could cause a redirection of some electrons from ferredoxin to $\mathrm{O}_{2}$ and reducing it via Mehler reaction to superoxide radical, which was then spontaneously dismutated to $\mathrm{H}_{2} \mathrm{O}_{2}$ by $\mathrm{Cu} / \mathrm{Zn}-\mathrm{SOD}$ (Polle 1996; Edreva 2005). However, Wiese et al. (1998) showed that oxygen reduction in the Mehler reaction was insufficient to protect photosystem I and II against photoinactivation. An important mechanism, preventing overloading of PSII with excitation energy during R2 treatment, was its effective transfer to PSI and then dissipation in the form of far-red fluorescence (Fig. 8a-c) (Baker 1991; Huner et al. 1998; Agati et al. 2000).

High level of hydrogen peroxide observed during R1 and R3 was accompanied by low activity of catalase (Fig. 4b) and peroxidases (Fig. 4c) as compared to gradual rehydration of leaf cells during R2 treatment. The fact that hydrogen peroxide content under stress depends on the antioxidant

Table 2 The content [ $\left.\mathrm{mg} \mathrm{g}^{-1} \mathrm{DW}\right]$ of chlorophyll $a$ and $b$ and carotenoids (Crt) in fully-recovered 'Hortenso' cultivar and not fullyrecovered 'Kazo' cultivar

\begin{tabular}{|c|c|c|c|c|c|c|c|c|}
\hline & \multicolumn{4}{|l|}{ 'Hortenso' } & \multicolumn{4}{|l|}{ 'Kazo' } \\
\hline & $\mathrm{C}$ & $\mathrm{D}$ & R1 & $\mathrm{C}$ & $\mathrm{D}$ & $\mathrm{R} 1$ & $\mathrm{R} 2$ & R3 \\
\hline Chl $a$ & $37.6 \pm 1.38 \mathrm{a}$ & $28.3 \pm 2.07 b$ & $37.1 \pm 2.80 \mathrm{a}$ & $40.3 \pm 1.06 \mathrm{a}$ & $33.4 \pm 1.04 \mathrm{~b}$ & $38.2 \pm 2.36 \mathrm{a}$ & $41.9 \pm 1.18 \mathrm{a}$ & $40.1 \pm 1.18 \mathrm{a}$ \\
\hline Chl $b$ & $12.7 \pm 0.90 \mathrm{a}$ & $8.4 \pm 0.60 \mathrm{~b}$ & $12.3 \pm 0.69 \mathrm{a}$ & $14.6 \pm 0.60 \mathrm{a}$ & $11.6 \pm 0.98 b$ & $15.2 \pm 0.64 \mathrm{a}$ & $14.5 \pm 0.77 \mathrm{a}$ & $14.3 \pm 0.56 \mathrm{a}$ \\
\hline $\mathrm{Crt}$ & $8.5 \pm 0.30 \mathrm{a}$ & $5.9 \pm 0.45 b$ & $8.3 \pm 0.53 a$ & $8.5 \pm 0.31 \mathrm{a}$ & $6.7 \pm 0.27 b$ & $8.4 \pm 0.35 \mathrm{a}$ & $8.4 \pm 0.28 \mathrm{a}$ & $8.7 \pm 0.30 \mathrm{a}$ \\
\hline
\end{tabular}

The analyses were performed after 3 weeks of drought and after 7 days of rehydration. $C$-control, $D$-drought, $R 1 / R 2 / R 3$-rehydration. Duncan's test at 0.05 probability level was performed in order to determine the significance of differences between treatment means. Means indicated with the same letters within cultivar and chlorophyll fluorescence parameters were not significantly different. Means \pm SE $(n=7)$ 
Table 3 Relative water content (RWC, [\%]), leaf water potential ( $\left.\Psi_{\mathrm{w}},[\mathrm{MPa}]\right)$, content of assimilation pigments (Chl $a$-chlorophyll $a$; Chl $b$-chlorophyll $b$; Crt-carotenoids, [ $\left.\left.\mathrm{mg} \mathrm{g}^{-1} \mathrm{DW}\right]\right)$, hydrogen peroxide $\left(\mathrm{H}_{2} \mathrm{O}_{2}\right.$, [ $\left.\left.\mu \mathrm{mol} \mathrm{H}_{2} \mathrm{O}_{2} \mathrm{~g}^{-1} \mathrm{DW}\right]\right)$ and activity of antioxidant enzymes (POX - peroxidase, [units $\mathrm{min}^{-1} \mathrm{mg}^{-1}$ (prot.)]; CATcatalase, [ $\mu \mathrm{mol} \mathrm{H}_{2} \mathrm{O}_{2} \mathrm{~min}^{-1} \mathrm{mg}^{-1}$ (prot.)] in flag leaves of fullyrecovered Hortenso' cultivar and not fully-recovered 'Kazo' cultivar on $42^{\text {nd }}$ day of the rehydration

\begin{tabular}{|c|c|c|c|c|c|c|}
\hline & \multicolumn{3}{|l|}{ 'Hortenso' } & \multicolumn{3}{|l|}{ 'Kazo’' } \\
\hline & $\mathrm{C}$ & $\mathrm{R} 1$ & $\mathrm{C}$ & $\mathrm{R} 1$ & $\mathrm{R} 2$ & $\mathrm{R} 3$ \\
\hline RWC & $93.7 \pm 1.06 \mathrm{a}$ & $93.1 \pm 0.87 \mathrm{a}$ & $94.0 \pm 1.65 \mathrm{a}$ & $94.3 \pm 1.23 \mathrm{a}$ & $94.7 \pm 0.71 \mathrm{a}$ & $94.4 \pm 1.42 \mathrm{a}$ \\
\hline$\Psi_{\mathrm{w}}$ & $-0.80 \pm 0.07 \mathrm{a}$ & $-0.91 \pm 0.11 \mathrm{a}$ & $-0.86 \pm 0.10 \mathrm{a}$ & $-0.81 \pm 0.07 \mathrm{a}$ & $-0.87 \pm 0.08 \mathrm{a}$ & $-0.82 \pm 0.06 \mathrm{a}$ \\
\hline Chl $a$ & $39.9 \pm 2.24 \mathrm{a}$ & $41.3 \pm 2.29 a$ & $40.3 \pm 3.33 a$ & $39.7 \pm 2.44 a$ & $40.7 \pm 2.71 \mathrm{a}$ & $42.1 \pm 2.83 a$ \\
\hline Chl $b$ & $13.0 \pm 1.22 \mathrm{a}$ & $13.4 \pm 1.26 \mathrm{a}$ & $14.5 \pm 1.34 \mathrm{a}$ & $15.0 \pm 1.30 \mathrm{a}$ & $13.1 \pm 1.08 \mathrm{a}$ & $13.8 \pm 1.46 \mathrm{a}$ \\
\hline Crt & $8.8 \pm 0.91 \mathrm{a}$ & $9.0 \pm 0.76 \mathrm{a}$ & $9.3 \pm 0.77 \mathrm{a}$ & $8.7 \pm 0.74 a$ & $9.5 \pm 0.81 \mathrm{a}$ & $9.2 \pm 0.85 \mathrm{a}$ \\
\hline $\mathrm{H}_{2} \mathrm{O}_{2}$ & $12.9 \pm 0.66 \mathrm{a}$ & $13.2 \pm 0.84 \mathrm{a}$ & $11.9 \pm 1.08 \mathrm{a}$ & $13.3 \pm 0.69 \mathrm{a}$ & $14.2 \pm 1.01 \mathrm{a}$ & $12.3 \pm 0.49 \mathrm{a}$ \\
\hline POX & $40.7 \pm 2.64 \mathrm{a}$ & $44.1 \pm 1.68 \mathrm{a}$ & $40.3 \pm 2.22 \mathrm{a}$ & $40.9 \pm 1.90 \mathrm{a}$ & $44.5 \pm 2.83 \mathrm{a}$ & $46.4 \pm 1.60 \mathrm{a}$ \\
\hline CAT & $177.2 \pm 8.9 \mathrm{a}$ & $170.4 \pm 8.1 \mathrm{a}$ & $181.3 \pm 9.1 \mathrm{a}$ & $191.0 \pm 8.2 \mathrm{a}$ & $180.8 \pm 8.0 \mathrm{a}$ & $176.6 \pm 7.7 \mathrm{a}$ \\
\hline
\end{tabular}

$C$-control, R1/R2/R3-rehydration. Duncan's test at the 0.05 probability level was performed in order to determine the significance of differences between treatment means. Means indicated with the same letters within parameters were not significantly different. Means $\pm \mathrm{SE}$ ( $n=7$ for $\Psi_{\mathrm{w}}, \mathrm{chl} a$, chl $b$, crt, $\mathrm{H}_{2} \mathrm{O}_{2}, \mathrm{POX}, \mathrm{CAT} ; n=10$ for RWC)

status of a plant cell, associated e.g., with the activity of superoxide radical dismutase and $\mathrm{H}_{2} \mathrm{O}_{2}$ scavenging enzymes, has been confirmed by numerous authors (Fath et al. 2001; Neill et al. 2002; Srivalli et al. 2003). An increase in blue fluorescence excitation intensity (Fig. 5) may indicate another possible mode of $\mathrm{H}_{2} \mathrm{O}_{2}$ neutralization during $\mathrm{R} 2$ treatment. This type of fluorescence usually indicates the presence of phenolic compounds, mainly ferulic acid, associated with the cell wall carbohydrates (Lichtenthaler and Schweiger 1998). Schopfer (1996) proved that the incorporation of phenols in the cell wall is mediated by peroxidases and hydrogen peroxide as an oxidizing agent. The observed increase in the intensity of blue fluorescence excitation in R2 treatment may indicate one of the mechanisms for reducing the content of hydrogen peroxide in the process of phenolics incorporation in the cell wall. A similar increase in the intensity of emission or excitation of blue fluorescence from the plant leaves was observed under other environmental stresses that may be accompanied by a secondary oxidative stress (Lang et al. 1996; Schweiger et al. 1996).

High level of hydrogen peroxide was maintained also during R3 treatment at PPFD of $25 \mu \mathrm{mol} \mathrm{m} \mathrm{m}^{-2} \mathrm{~s}^{-1}$ (Fig. 4a and d). This may suggest an intensification of light-independent metabolic processes (e.g., mitochondrial electron transport chain, fatty acid $\beta$-oxidation, Mn-SOD activity in peroxisomes, NADH oxidase activity) that may also result in hydrogen peroxide formation (Møller 2001; del Río et al. 2006). It should be mentioned, however, that in PSII, even under lowlight conditions, the reactive oxygen species might be generated as by-products of photochemical reactions (Gill and Tuteja 2010).

The analyses performed in flag leaves revealed permanent changes in the photosynthetic activity in the not fully-recovered cv. 'Kazo' (Figs. 9 and 10). Changes in the parameters of chlorophyll fluorescence and photosynthetic activity, observed 7 days after finishing the drought period during R1 rehydration, were probably due to damage to the photosynthetic apparatus caused by ROS, including hydrogen peroxide (Miller et al. 2010). Moreover, hydrogen peroxide is involved in abscisic acid-induced stomatal closure (Zhang et al. 2001; Bright et al. 2006; Miao et al. 2006), which may be another reason for reduced photosynthetic activity after 7 days of R1 or R3 treatment.

Low photosynthetic activity of flag leaves at the generative development stage during R1 and R3 treatment is an example of a negative permanent effect of rapid rehydration. High level of hydrogen 
(a)

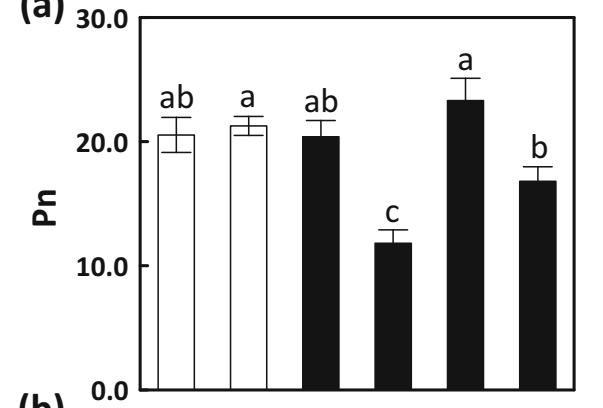

(b)

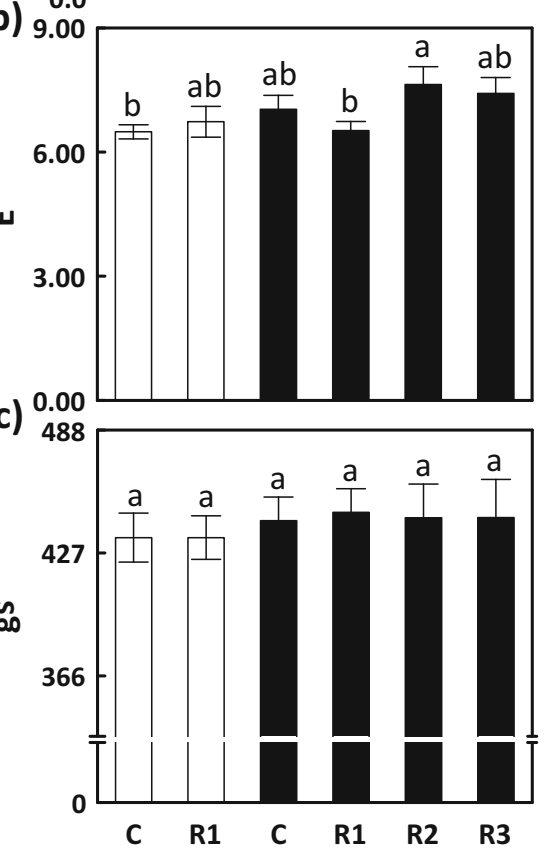

Fig. 9 Net photosynthetic activity (Pn, $\left.\left[\mu \mathrm{mol}\left(\mathrm{CO}_{2}\right) \mathrm{m}^{-2} \mathrm{~s}^{-1}\right]\right)$ (a), transpiration activity $\left(\mathrm{E},\left[\mathrm{mmol}\left(\mathrm{H}_{2} \mathrm{O}\right) \mathrm{m}^{-2} \mathrm{~s}^{-1}\right]\right)(\mathbf{b})$ and stomatal conductance (gs, $\left.\left[\mathrm{mmol}\left(\mathrm{CO}_{2}\right) \mathrm{m}^{-2} \mathrm{~s}^{-1}\right]\right)$ (c) for fully-recovered 'Hortenso' cultivar (white bars) and not fully-recovered 'Kazo' cultivar (black bars). The analyses were performed for flag leaves on the $42^{\text {nd }}$ day of rehydration. C-control, D-drought, R1/R2/R3rehydration. Duncan's test at 0.05 probability level was performed in order to determine the significance of differences between treatment means. Means indicated with the same letters within the investigated parameters were not significantly different. Means $\pm \mathrm{SE}(n=10)$

peroxide that acts as a secondary cellular messenger could induce the expression of genes controlling photosynthetic activity during $\mathrm{R} 1$ and R3 treatment (Foyer et al. 1997; Mittler 2002; Mittler et al. 2004). Low photosynthetic activity observed during R1 and R3 rehydration was not caused by disturbances in the stomatal conductance (Fig. 9c), changes in chlorophyll content or leaf water content (Table 3). It was also not due to differences in hydrogen peroxide content or activity of antioxidant enzymes (Table 3). Measurements of the flag leaves chlorophyll fluorescence during R1 and R3 treatment (Fig. 10) revealed that the reduced rate of photosynthesis could be caused by disturbances in the photosynthetic apparatus activity (BolharNordenkampf and Öquist 1993; Maxwell and Johnson 2000; Baker and Rosenqvist 2004). Permanent and unfavorable changes in the photosynthetic activity of the flag leaves in not fully-recovered cv. 'Kazo' triggered by R1 and R3 treatment involved also a drop in the efficiency of excitation energy transfer between PSII and PS I (Fig. 10g and h) (Huner et al. 1998; Tikkanen and Aro 2012).

Hydrogen peroxide is the most stable and longdistance ROS signaling molecule that regulates stress responses and developmental processes in plants (Vranová et al. 2002). Vandenabeele et al. (2002) showed that hydrogen peroxide could provoke transcriptional responses that mimicked both biotic and abiotic stresses. Therefore, sustained increases in $\mathrm{H}_{2} \mathrm{O}_{2}$ content under rapid rehydration could also induce genes expression involved in physiological adjustments, e.g., the photosynthetic apparatus activity. It has been known since the 1970 s that an increase in hydrogen peroxide content affects the activity of the Calvin cycle enzymes (Kaiser 1979). Tanou et al. (2009) reported that plants exposed to $\mathrm{H}_{2} \mathrm{O}_{2}$ activated specific proteome reprogramming to prevent accumulation of proteins, e.g., the key enzymes of the Calvin cycle (Rubisco activase, Rubisco large subunit, fructose 1,6-bisphosphate aldolase, phosphoglycerate kinase, glyceraldehyde-3-phosphate dehydrogenase, phosphoribulokinase, transketolase and carbonic anhydrase). Hence, it may be speculated that the impact of rapid rehydration after drought at the tillering stage on low photosynthesis during the reproductive phase is connected with $\mathrm{H}_{2} \mathrm{O}_{2}$-induced gene expression related to persistent limitation in $\mathrm{CO}_{2}$ assimilation.

Our results indicate that rapid rehydration can initiate adverse changes in the activity of the photosynthetic apparatus. Therefore, to show a comprehensive process of plant acclimation to drought, 
Fig. 10 The maximum potential PSII efficiency $\left(\mathrm{F}_{\mathrm{v}} / \mathrm{F}_{\mathrm{m}}\right)(\mathbf{a})$, the efficiency of excitation transfer to open PSII centers $\left(\mathrm{F}_{\mathrm{v}}{ }^{\prime} / \mathrm{F}_{\mathrm{m}}{ }^{\prime}\right)(\mathbf{b})$, PSII quantum efficiency $\left(\Phi_{\mathrm{PSII}}\right)$ (c), photochemical quenching coefficient $\left(\mathrm{q}_{\mathrm{P}}\right)(\mathbf{d})$, nonphotochemical quenching coefficient $\left(\mathrm{q}_{\mathrm{N}}\right)(\mathrm{e})$ and the electron transport rate (ETR, [ $\mu \mathrm{mol}$ electrons $\left.\mathrm{m}^{-2} \mathrm{~s}^{-1}\right]$ ) (f) for fully-recovered 'Hortenso' cultivar (white bars) and not fully-recovered 'Kazo' cultivar (black bars). The analyses were performed for flag leaves on the $42^{\text {nd }}$ day of rehydration. Ccontrol, D-drought, R1/R2/R3rehydration. Duncan's test at 0.05 probability level was performed in order to determine the significance of differences between treatment means. Means indicated with the same letters within the investigated parameters were not significantly different. Means $\pm \operatorname{SE}(n=10)$. g$\mathbf{h}$ Changes in the emission intensity of red fluorescence $\left(\mathrm{F}_{690}\right)$ and far-red fluorescence $\left(\mathrm{F}_{740}\right)$ depending on the number of point excitation events (from 1 to 10,1-min interval) of the same fragment of a flag leaf with light of $450 \mathrm{~nm}$ in not fully-recovered 'Kazo' cultivar on the $42^{\text {nd }}$ day of rehydration. There were ten excitation events for 10 leaves in R1, R2 and R3 treatments. Each excitation event was followed by reading the intensity of red and far-red fluorescence emission.

R1-white squares, R2-gray squares, R3-black squares. Means \pm SE $(n=10)$
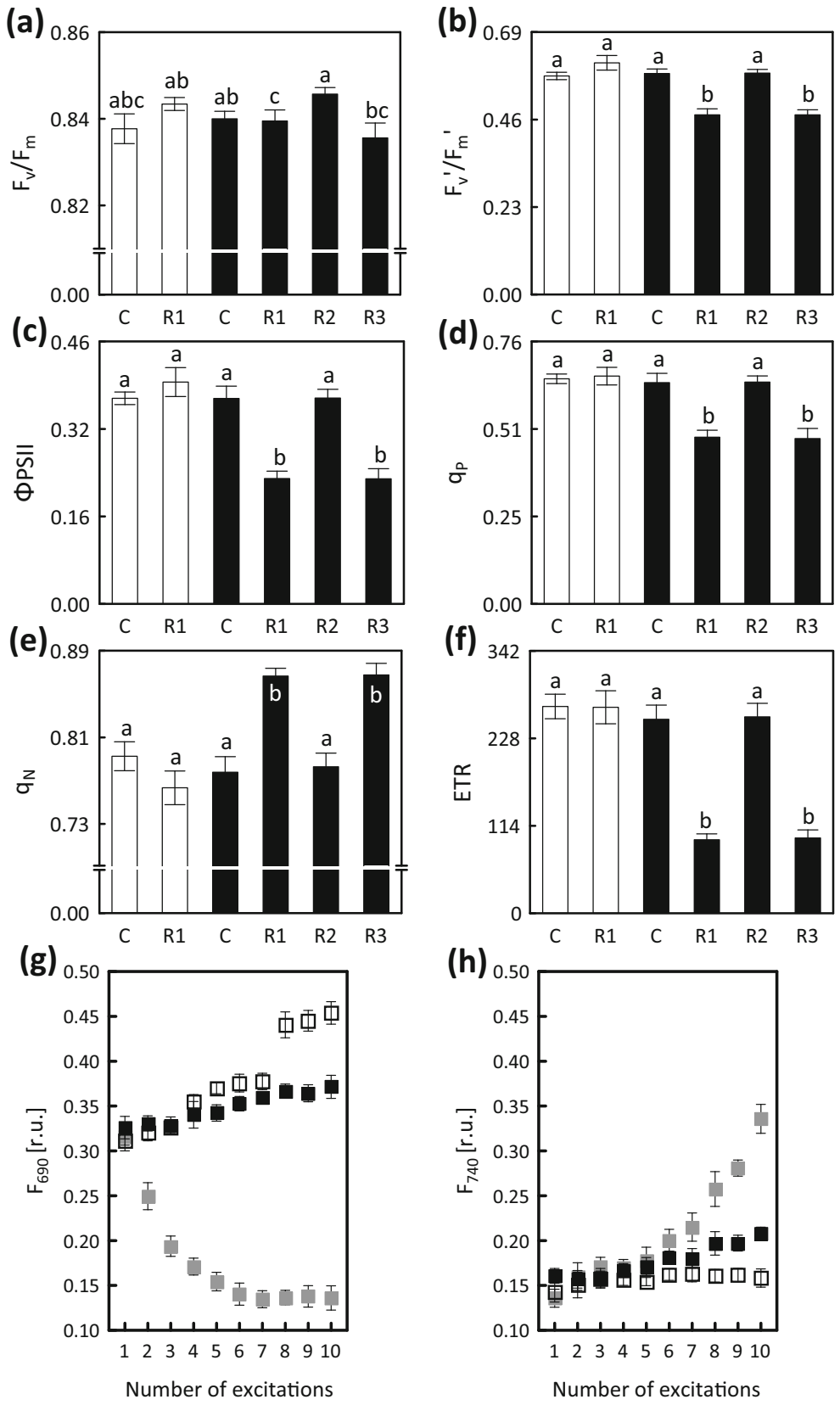

this rehydration stage should be taken into account in the experiments aimed at a selection of cultivars resistant to soil drought and during the search for the genome regions related to the resistance to soil water deficit. Further studies are currently being conducted to elucidate the molecular mechanisms of the photosynthetic apparatus acclimation in the rehydration conditions.

\section{Conclusions}

This study has proved that rapid rehydration, occurring after soil drought at the tillering stage, caused negative changes manifested by lowered photosynthetic activity of the flag leaves and, consequently, a significant drop in triticale grain weight. We suggest that, despite rehydration of triticale leaves, further 


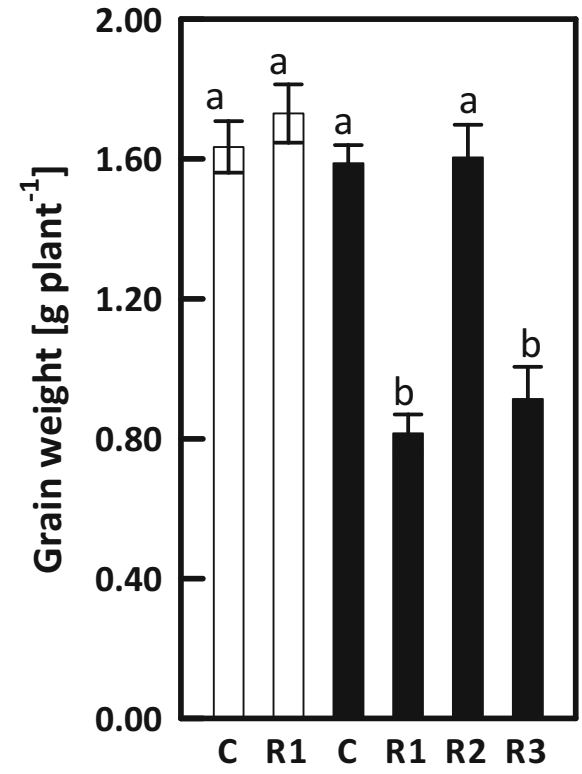

Fig. 11 Analysis of grain yield for fully-recovered 'Hortenso' cultivar (white bars) and not fully-recovered 'Kazo' cultivar (black bars). C-control, D-drought, R1/R2/R3-rehydration. Duncan's test at 0.05 probability level was performed in order to determine the significance of differences between treatment means. Means indicated with the same letters within cultivar were not significantly different. Means \pm SE $(n=18)$

accumulation of hydrogen peroxide during the rehydration at the tillering stage was a biochemical factor determining full or partial recovery of triticale. A destructive effect of the rapid rehydration was manifested in an intensification of the physiological processes associated with reactive oxygen species (ROS) production. An important cause of hydrogen peroxide overproduction could be the electron leakage due to overloading of the electron transport chain (ETC) in PSI and PSII.

Open Access This article is distributed under the terms of the Creative Commons Attribution 4.0 International License (http:// creativecommons.org/licenses/by/4.0/), which permits unrestricted use, distribution, and reproduction in any medium, provided you give appropriate credit to the original author(s) and the source, provide a link to the Creative Commons license, and indicate if changes were made.

\section{References}

Aebi H (1984) Catalase in vitro. In: Willam BJ (ed) Methods in enzymology. Academic, New York, pp 121-126
Agati G, Cerovic ZG, Moya I (2000) The effect of decreasing temperature up to chilling values on the in vivo F685/F735 chlorophyll fluorescence ratio in Phaseolus vulgaris and Pisum sativum: the role of the photosystem I contribution to the $735 \mathrm{~nm}$ fluorescence band. Photochem Photobiol 72:75-84

Apel K, Hirt H (2004) Reactive oxygen species: metabolism, oxidative stress, and signal transduction. Annu Rev Plant Biol 55:373-39

Asada K (2006) Production and scavenging of reactive oxygen species in chloroplasts and their functions. Plant Physiol 141: 391-396

Baker NR (1991) A possible role for photosystem II in environmental perturbations of photosynthesis. Physiol Plant 81: 563-570

Baker NR, Rosenqvist E (2004) Applications of chlorophyll fluorescence can improve crop production strategies: an examination of future possibilities. J Exp Bot 55:1607-1621

Barnabás B, Jäger K, Fehér A (2008) The effect of drought and heat stress on reproductive processes in cereals. Plant Cell Environ 31:11-38

Barrs HD, Weatherley PE (1962) A re-examination of the relative turgidity techniques for estimating water deficits in leaves. Aust J Biol Sci 15:413-428

Bartosz G (1997) Oxidative stress in plants. Acta Physiol Plant 19: 47-64

Beckett M, Loreto F, Velikova V, Brunetti C, Di Ferdinando M, Tattini M, Calfapietra C, Farrant JM (2012) Photosynthetic limitations and volatile and non-volatile isoprenoids in the poikilochlorophyllous resurrection plant Xerophyta humilis during dehydration and rehydration. Plant Cell Environ 35:20612074

Bergmeyer HU (1965) Methods of enzymatic analysis. Verlag Chemie G.m.b.H., Weinheim/Bergstr. Academic Press, New York and London

Blokhina O, Virolainen E, Fagerstedt KV (2002) Antioxidants, oxidative damage and oxygen deprivation stress: a review. Ann Bot 91:179-194

Bolhar-Nordenkampf HR, Öquist G (1993) Chlorophyll fluorescence as a tool in photosynthesis research. In: Hall DO, Scurlock JMO, Bolhàr-Nordenkampf HR, Leegood RC, Long SP (eds) Photosynthesis and production in a changing environment: a field and laboratory manual. Chapman \& Hall, London, pp 193-206

Borrell AK, Mullet JE, George-Jaeggli B, van Oosterom EJ, Hammer GL, Klein PE, Jordan DR (2014) Drought adaptation of stay-green sorghum is associated with canopy development, leaf anatomy, root growth, and water uptake. J Exp Bot 65:6251-6263

Bradford MM (1976) A rapid and sensitive method for the quantitation of microgram quantities of protein utilizing the principle of protein-dye binding. Anal Biochem $72: 248-254$

Bright J, Desikan R, Hancock JT, Weir IS, Neill SJ (2006) ABAinduced NO generation and stomatal closure in Arabidopsis are dependent on $\mathrm{H}_{2} \mathrm{O}_{2}$ synthesis. Plant J 45:113-122

Cannell RQ, Belford RK, Gales K, Thomson RJ, Webster CP (1984) Effects of waterlogging and drought on winter wheat and winter barley grown on a clay and a sandy loam soil. Plant Soil 80:53-66

del Río LA, Sandalio LM, Corpas FJ, Palma JM, Barroso JB (2006) Reactive oxygen species and reactive nitrogen species 
in peroxisomes. production, scavenging, and role in cell signalling. Plant Physiol 141:330-335

Doke N, Ohashi Y (1988) Involvement of and $\mathrm{O}_{2}{ }^{--}$generating system in the induction of necrotic lesions on tobacco leaves infected with tobacco mosaic virus. Physiol Mol Plant Pathol $32: 165-175$

Edreva A (2005) Generation and scavenging of reactive oxygen species in chloroplasts: a submolecular approach. Agric Ecosyst Environ 106:119-133

Escalona JM, Flexas J, Medrano H (2000) Stomatal and nonstomatal limitations of photosynthesis under water stress in field-grown grapevines. Aust J Plant Physiol 27:87-87

Fath A, Bethke PC, Jones RL (2001) Enzymes that scavenge reactive oxygen species are down-regulated prior to gibberellic acid-induced programmed cell death in barley aleurone. Plant Physiol 126:156-166

Flexas J, Medrano H (2002) Energy dissipation in $\mathrm{C}_{3}$ plants under drought. Funct Plant Biol 29:1209-1215

Flexas J, Escalona JM, Medrano H (1999) Water stress induces different levels of photosynthesis and electron transport rate regulation in grapevines. Plant Cell Environ 22:39-48

Flexas J, Ribas-Carbó M, Bota J, Galmés J, Henkle M, Martínez-Cañellas S, Medrano H (2006) Decreased Rubisco activity during water stress is not induced by decreased relative water content but related to conditions of low stomatal conductance and chloroplast $\mathrm{CO}_{2}$ concentration. New Phytol 172:73-82

Foyer CH, Lopez-Delgado H, Dat JF, Scott IM (1997) Hydrogen peroxide- and glutathione-associated mechanisms of acclimatory stress tolerance and signalling. Physiol Plant 100:241-254

Furlan AL, Bianucci E, Tordable MC, Castro S, Dietz KJ (2014) Antioxidant enzyme activities and gene expression patterns in peanut nodules during a drought and rehydration cycle. Funct Plant Biol 41:704-713

Genty B, Briantais JM, Adams WW (1989) The relationship between the quantum yield of photosynthetic electron transport and quenching of chlorophyll fluorescence. Biochim Biophys Acta 990:87-92

Gill SS, Tuteja N (2010) Reactive oxygen species and antioxidant machinery in abiotic stress tolerance in crop plants. Plant Physiol Biochem 48:909-930

Grzesiak MT, Filek W, Hura T, Kocurek M, Pilarski J (2010) Leaf optical properties during and after drought stress in triticale and maize genotypes differing in drought tolerance. Acta Physiol Plant 32:433-442

Hoagland DR (1948) Lectures on the inorganic nutrition of plants. Chronica Botanica Co, Waltham

Huner NPA, Öquist G, Sarhan F (1998) Energy balance and acclimation to light and cold. Trends Plant Sci 3:224230

Hura T, Grzesiak S, Hura K, Grzesiak MT, Rzepka A (2006) Differences in the physiological state between triticale and maize plants during drought stress and followed rehydration expressed by the leaf gas exchange and spectrofluorimetric methods. Acta Physiol Plant 5:433-443

Hura T, Grzesiak S, Hura K, Thiemt E, Tokarz K, Wedzony M (2007a) Physiological and biochemical tools useful in drought-tolerance detection in genotypes of winter triticale: accumulation of ferulic acid correlates with drought tolerance. Ann Bot 100:767-775
Hura T, Hura K, Grzesiak MT, Rzepka A (2007b) Effect of longterm drought stress on leaf gas exchange and fluorescence parameters in $\mathrm{C}_{3}$ and $\mathrm{C}_{4}$ plants. Acta Physiol Plant 29:103-113

Hura T, Hura K, Grzesiak S (2009a) Possible contribution of cell wall-bound ferulic acid in drought resistance and recovery in triticale seedlings. J Plant Physiol 166:1720-1733

Hura T, Hura K, Grzesiak S (2009b) Physiological and biochemical parameters for identifications of QTLs controlling the winter triticale drought tolerance at the seedling stage. Plant Physiol Biochem 47:210-214

Hura T, Hura K, Grzesiak S (2009c) Leaf dehydration induces different content of phenolics and ferulic acid in droughtresistant and -sensitive genotypes of spring triticale. $\mathrm{Z}$ Naturforsch 64c:85-95

Hura T, Hura K, Grzesiak M (2011) Soil drought applied during the vegetative growth of triticale modifies physiological and biochemical adaptation to drought during the generative development. J Agron Crop Sci 197:113-123

Hura T, Hura K, Dziurka K, Ostrowska A, Baczek-Kwinta R, Grzesiak MT (2012) An increase in the content of cell wallbound phenolics correlates with the productivity of triticale under soil drought. J Plant Physiol 169:1728-1736

Hura K, Hura T, Dziurka K, Dziurka M (2014) Biochemical defense mechanisms induced in winter oilseed rape seedlings with different susceptibility to infection with Leptosphaeria maculans. Physiol Mol Plant Pathol 87:42-50

Ishikawa T, Takeda T, Shigeoka S, Hirayama O, Mitsunaga T (1993) Hydrogen peroxide generation in organelles of Euglena gracilis. Phytochemistry 33:1297-1299

Kaiser WM (1979) Reversible inhibition of the Calvin cycle and activation of oxidative pentose phosphate cycle in isolated intact chloroplasts by hydrogen peroxide. Planta 145:377-382

Lang M, Lichtenthaler HK, Sowinska M, Heisel F, Miehé JA (1996) Fluorescence imaging of water and temperature stress in plant leaves. J Plant Physiol 148:613-621

Lichtenthaler HK, Schweiger J (1998) Cell wall bound ferulic acid, the major substance of the blue-green fluorescence emission of plants. J Plant Physiol 152:272-282

Lichtenthaler HK, Wellburn RR (1983) Determination of total carotenoids and chlorophylls $a$ and $b$ of extracts in different solvents. Biochem Soc Trans 603:591-592

Lovisolo C, Perrone I, Hartung W, Schubert A (2008) An abscisic acid-related reduced transpiration promotes gradual embolism repair when grapevines are rehydrated after drought. New Phytol 180:642-651

Maksymiec W (2007) Signaling responses in plants to heavy metal stress. Acta Physiol Plant 29:177-187

Maxwell K, Johnson GN (2000) Chlorophyll fluorescence - a practical guide. J Exp Bot 51:659-668

Mayaba N, Minibayeva F, Beckett RP (2002) An oxidative burst of hydrogen peroxide during rehydration following desiccation in the moss Atrichum androgynum. New Phytol 155:275-283

McDowell N, Pockman WT, Allen CD, Breshears DD, Cobb N, Kolb T, Plaut J, Sperry J, West A, Williams DG, Yepez EA (2008) Mechanisms of plant survival and mortality during drought: why do some plants survive while others succumb to drought? New Phytol 178:719-739

Miao Y, Lv D, Wang P, Wang XC, Chen J, Miao C, Song CP (2006) An Arabidopsis glutathione peroxidase functions as both a redox transducer and a scavenger in abscisic acid and drought stress responses. Plant Cell 18:2749-2766 
Miller G, Suzuki N, Ciftci-Yilmaz S, Mittler R (2010) Reactive oxygen species homeostasis and signalling during drought and salinity stresses. Plant Cell Environ

Minibayeva F, Beckett RP (2001) High rates of extracellular superoxide production in bryophytes and lichens, and an oxidative burst in response to rehydration following desiccation. New Phytol 152:333-343

Mittler R (2002) Oxidative stress, antioxidants and stress tolerance. Trends Plant Sci 7:405-410

Mittler R, Vanderauwera S, Gollery M, van Breusegem F (2004) Reactive oxygen gene network of plants. Trends Plant Sci 9: 490-498

Møller IM (2001) Plant mitochondria and oxidative stress: electron transport, NADPH turnover, and metabolism of reactive oxygen species. Annu Rev Plant Physiol Plant Mol Biol 52:561-591

Nedbal L, Soukupová J, Kaftan D, Whitmarsh J, Trtílek M (2000) Kinetic imaging of chlorophyll fluorescence using modulated light. Photosynth Res 66:3-12

Neill S, Desikan R, Hancock J (2002) Hydrogen peroxide signalling. Curr Opin Plant Biol 5:388-395

Nolf M, Pagitz K, Mayr S (2014) Physiological acclimation to drought stress in Solidago canadensis. Physiol Plant 150: 529-539

O'Grady AP, Mitchell PJM, Pinkard EA, Tissue DT (2013) Thirsty roots and hungry leaves: unravelling the roles of carbon and water dynamics in tree mortality. New Phytol 200:294-297

Oliver MJ, O’Mahony P, Wood AJ (1998) 'To dryness and beyond' - preparation for the dried state and rehydration in vegetative desiccation-tolerant plants. Plant Growth Regul 24:193-201

Orozco-Cárdenas ML, Narváez-Vásquez J, Ryan CA (2001) Hydrogen peroxide acts as a second messenger for the induction of defense genes in tomato plants in response to wounding, systemin, and methyl jasmonate. Plant Cell 13:179-191

Polle A (1996) Mehler reaction: friend or foe in photosynthesis? Bot Acta 109:84-89

Proctor MCF, Smirnoff N (2000) Rapid recovery of photosystems on rewetting desiccation-tolerant mosses: chlorophyll fluorescence and inhibitor experiments. J Exp Bot 51:1695-1704

Rollins JA, Habte E, Templer SE, Colby T, Schmidt J, von Korff M (2013) Leaf proteome alterations in the context of physiological and morphological responses to drought and heat stress in barley (Hordeum vulgare L.). J Exp Bot 64:3201-3212

Saini HS, Westgate ME (2000) Reproductive development in grain crops during drought. In: Spartes DL (ed) Advances in agronomy. Academic, San Diego, pp 59-96

Sala A, Piper F, Hoch G (2010) Physiological mechanisms of drought-induced tree mortality are far from being resolved. New Phytol 186:274-281

Schopfer P (1996) Hydrogen peroxide-mediated cell-wall stiffening in vitro in maize coleoptiles. Planta 199:43-49

Schweiger J, Lang M, Lichtenthaler HK (1996) Differences in fluorescence excitation spectra of leaves between stressed and non-stressed plants. J Plant Physiol 148:536-547

Sevanto S, McDowell NG, Dickman LT, Pangle R, Pockman WT (2014) How do trees die? A test of the hydraulic failure and carbon starvation hypotheses. Plant Cell Environ 37:153-161

Shah NH, Paulsen GM (2003) Interaction of drought and high temperature on photosynthesis and grain-filling of wheat. Plant Soil 257:219-226
Souza RP, Machado EC, Silva JAB, Lagôa AMMA, Silveira JAG (2004) Photosynthetic gas exchange, chlorophyll fluorescence and some associated metabolic changes in cowpea (Vigna unguiculata) during water stress and recovery. Environ Exp Bot 51:45-56

Srivalli B, Sharma G, Khanna-Chopra R (2003) Antioxidative defense system in an upland rice cultivar subjected to increasing intensity of water stress followed by recovery. Physiol Plant 119:503-512

Strasser RJ, Tsimilli-Michael M (2001) Stress in plants, from daily rhythm to global changes, detected and quantified by the JIPTest. Chim Nouv 75:3321-3326

Strasser RJ, Tsimilli-Michael M, Qiang S, Goltsev V (2010) Simultaneous in vivo recording of prompt and delayed fluorescence and $820 \mathrm{~nm}$ reflection changes during drying and after rehydration of the resurrection plant Haberlea rhodopensis. Biochim Biophys Acta 1797:1313-1326

Takahashi M, Shiraishi T, Asada K (1988) Superoxide production in aprotic interior of chloroplast thylakoids. Arch Biochem Biophys 267:714-722

Tanou G, Job C, Rajjou L, Arc E, Belghazi M, Diamantidis G, Molassiotis A, Job D (2009) Proteomics reveals the overlapping roles of hydrogen peroxide and nitric oxide in the acclimation of citrus plants to salinity. Plant J 60:795-804

Thordal-Christensen H, Zhang Z, Wei Y, Collinge DB (1997) Subcellular localization of $\mathrm{H}_{2} \mathrm{O}_{2}$ in plants. $\mathrm{H}_{2} \mathrm{O}_{2}$ accumulation in papillae and hypersensitive response during the barleypowdery mildew interaction. Plant J 11:1187-1194

Tikkanen M, Aro EM (2012) Thylakoid protein phosphorylation in dynamic regulation of photosystem II in higher plants. Biochim Biophys Acta 1817:232-238

Tsimilli-Michael M, Strasser RJ (2008) In vivo assessment of plant's vitality: applications in detecting and evaluating the impact of mycorrhization on host plants. In: Varma A (ed) Mycorrhiza, state of the art, genetics, and molecular biology, eco-function, biotechnology, eco-physiology, structure, and systematics, 3rd edn. Springer, Dordrecht, pp 679-703

Turner NC (1981) Techniques and experimental approaches for the measurement of plant water status. Plant Soil 58:339-366

van Kooten O, Snel FH (1990) The use of chlorophyll fluorescence nomenclature in plant stress physiology. Photosynth Res 25:147-150

Vandenabeele S, Van Der Kelen K, Dat J, Gadjev I, Boonefaes T, Morsa S, Rottiers P, Slooten L, Van Montagu M, Zabeau M, Inzé D, Van Breusegem F (2002) A comprehensive analysis of hydrogen peroxide-induced gene expression in tobacco. Proc Natl Acad Sci U S A 100:16113-16118

Vranová E, Inzé D, Van Breusegem F (2002) Signal transduction during oxidative stress. J Exp Bot 53:1227-1236

Weissman L, Garty J, Hochman A (2005) Rehydration of the lichen Ramalina lacera results in production of reactive oxygen species and nitric oxide and a decrease in antioxidants. Appl Environ Microbiol 71:2121-2129

Wiese C, Shi LB, Heber U (1998) Oxygen reduction in the Mehler reaction is insufficient to protect photosystems I and II of leaves against photoinactivation. Physiol Plant 102:437-446

Yang JC, Zhang JH (2006) Grain filling of cereals under soil drying. New Phytol 169:223-236

Zhang X, Zhang L, Dong F, Gao J, Galbraith DW, Song CP (2001) Hydrogen peroxide is involved in abscisic acid-induced stomatal closure in Vicia faba. Plant Physiol 126:1438-1448 